УДК 550.4: 548.4

\title{
ЭВОЛЮЦИЯ ФИЗИКО-ХИМИЧЕСКИХ УСЛОВИЙ КРИСТАЛЛИЗАЦИИ РАСПЛАВОВ ПРИ ФОРМИРОВАНИИ ДУНИТ-ПЕРИДОТИТ-ГАББРОВЫХ МАССИВОВ ВОСТОЧНОГО САЯНА
}

\section{Ступаков Сергей Иванович',}

stupakov@igm.nsc.ru

\author{
Симонов Владимир Александрович ${ }^{1,2,3}$, \\ simonov@igm.nsc.ru \\ Мехоношин Алексей Сергеевич4, \\ mekhonos@igc.irk.ru

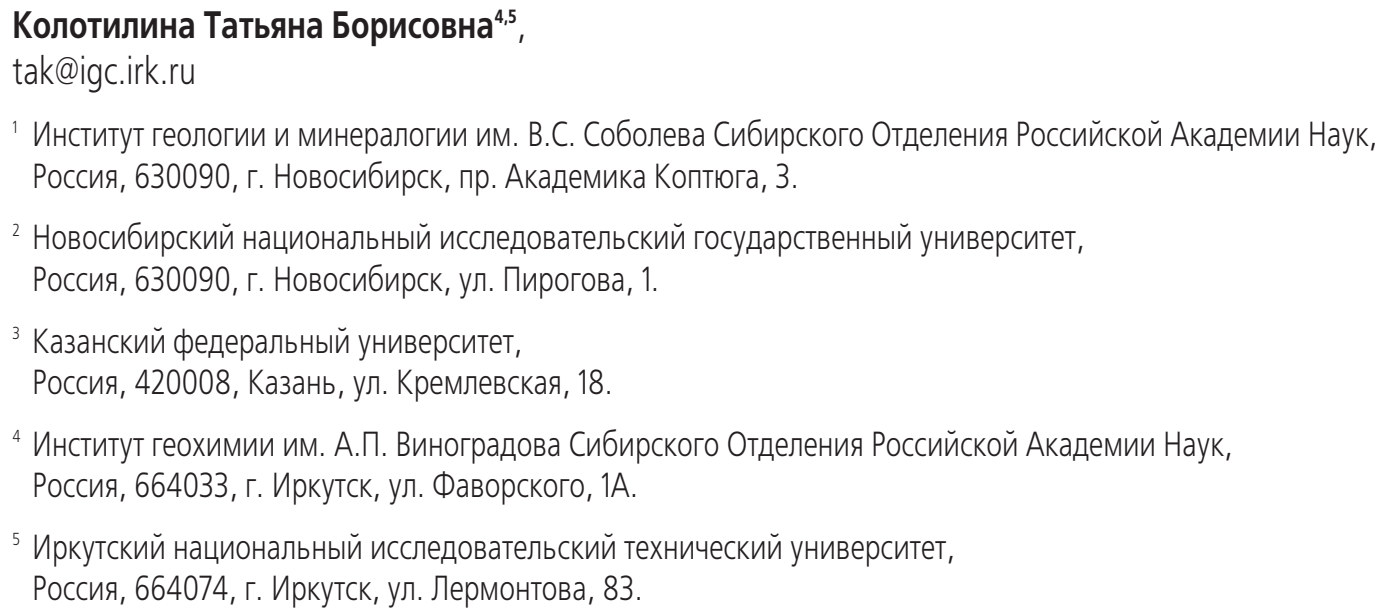

Актуальность. Изучение расплавных включений в минералах является одним из наиболее достоверных путей получения прямой информации о характере магматических процессов, позволяет построить модель образования интрузий и проследить эволюцию физико-химических условий кристаллизации магматических комплексов.

Цель: получить достоверные сведения о составе расплава, что дает возможность проследить эволюцию физико-химических условий образования пород платиноносного дунит-верлитового массива Медек.

Объекты: расплавные включения в хромшпинелидах дунитов и верлитов Медекского базит-ультрабазитового массивов.

Методы. Поиск расплавных включений проводился в монофракциях акцессорных хромшпинелидов из дунитов и верлитов массива. Полированные препараты просматривались под микроскопом, и отбирались зерна, содержащие многофазные микровключения определённой формы, размера (10-30 мкм) и положения внутри зерна. Далее проводились высокотемпературные эксперименты. Выбор температурного режима $\left(1280-1300^{\circ} \mathrm{C}\right)$ определялся задачей перевести включения в расплавленное состояние, затем его закалить, и полученное стекло проанализировать на рентгеновском микроанализаторе и сканирующем микроскопе.

Результаты. В результате анализа стекол гомогенизированных расплавных включений установлено, что состав родоначальной магмы, из которой кристаллизовались дуниты массива, отвечал пикритоидному расплаву (МgO 13,36 мас. \%), который эволюционировал до низкокалиевого пикробазальтового расплава, наиболее близкого по петрохимическим характеристикам к данным по расплавным включениям в хромитах из океанических комплексов. Геотермобарометрические расчеты и моделирование с помощью программ COMAGMAT и PETROLOG свидетельствуют о становлении пород массива при давлении 3-5 кбар и температурном диапазоне $1400-1230{ }^{\circ} \mathrm{C}$. Расчетные данные и результаты высокотемпературных экспериментов показали хорошую сходимость.

\section{Ключевые слова:}

Медекский массив, ультрабазиты, дуниты, верлиты, хромшпинелиды, расплавные включения.

\section{Введение}

При исследовании рудоносности базит-ультрабазитовых комплексов большое внимание уделяется генетическим проблемам [1-4]. На оценку перспектив платиноносности, прежде всего, влияют представления об условиях формирования пород [5-8] и составе исходной магмы. Ранее было обосновано, что изучение расплавных включений в минералах является одним из наиболее достоверных путей получе- ния прямой информации о характере магматических процессов [9-20]. На примере ряда массивов Сибирского кратона $[13,14,16,21]$, в том числе и дунит-перидотит-габбровых массивов Восточного Саяна [22, 23], ранее была доказана эффективность применения разработанной нами методики [14] исследования расплавных включений в хромшпинелидах при изучении рудно-магматических систем, связанных с базит-ультрабазитовыми комплексами. 
В настоящей статье представлены новые данные по минералам и расплавным включениям в хромшпинелидах дунит-верлитового массива Медек, результаты компьютерной обработки оригинальной информации по составам минералов и включений, с помощью минералогических термометров и барометров, а также программ COMAGMAT [24-26] и PETROLOG [27], которые позволили выяснить особенности эволюции физико-химических параметров магматических систем при его формировании.

\section{Геолого-петрографические особенности пород массива Медек}

Массив Медек расположен в центральной части Восточного Саяна, в междуречье Мал. Бирюса Уда (рис. 1, врезка). Форма массива в плане эллипсовидная, длинная ось вытянута в субмеридиональном направлении, площадь выхода составляет около $2 \mathrm{kм}^{2}$ (рис. 1). Хотя непосредственные границы с вмещающими породами не наблюдаются, о тектоническом характере взаимоотношений говорят отрицательные формы рельефа, развитые на контактах зоны милонитизации и катаклаза, сопровождающиеся метаморфогенным преобразованием пород.

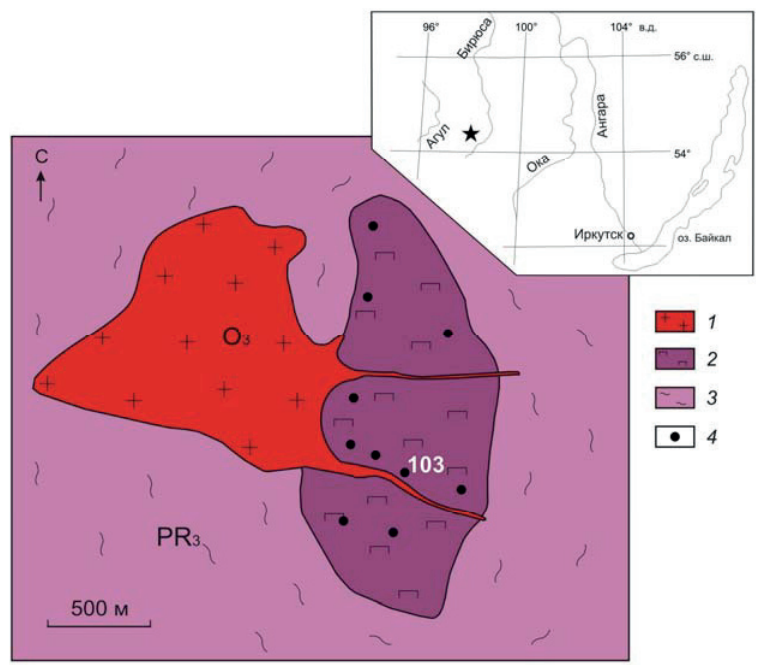

Pис.1. Местоположение (врезка) и схематическая геологическая карта массива Медек (рисунок составлен на основе оригинальных данных с использованием материалов из работ [22, 28]). 1 - граниты, сиениты, диориты; 2 - уль табазиты; 3 -гнейсы, сланиы, алфиболиты; 4-положе ние скважин

Fig. 1. Location (inset) and schematic geological map of the Medek massif (figure is based on the original data using materials from the works [22, 28]). 1 - granites, syenites, diorites; 2 ultrabasites; 3 - gneisses, shales, amphibolites; 4 - the position of boreholes

Массив Медек сложен дунит-верлитовой дифференцированной серией пород с постепенными переходами между петрографическими разностями. Дуниты массива среднезернистые, микроструктура пород кумулятивная с чётко проявленным идиоморфизмом зёрен оливина. Интеркуму- лусный пироксен по составу отвечает хромдиопсиду. Главным акцессорным минералом является хромшпинелид. Для верлитов характерны кумулятивные и пойкилитовые структуры. В качестве акцессорного минерала в них кроме хромшпинелида появляется ильменит, который иногда находится с ним в тесном срастании. Породы массива в различной степени преобразованы низкотемпературными постмагматическими процессами, вплоть до образования в краевых частях хлоритсерпентиновых и актинолитовых сланцев.

Оруденение в массиве представлено в основном вкрапленными сульфидными рудами, которые состоят главным образом из пентландита, в переменных количествах присутствует халькопирит, троилит и кубанит. Максимальное количество сульфидов достигает 10 об. \%. Минералы платиновой группы представлены главным образом сперрилитом и различными висмуто-теллуридами палладия. Первичные минеральные ассоциации были преобразованы в условиях низких уровней фугитивности кислорода и серы в системе [23]. При этом в крайних случаях происходило образование аваруита и самородной меди и замещение сперрилита

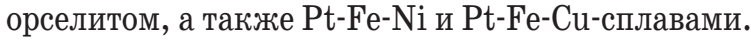

\section{Образцы и методы исследования}

Поиск расплавных включений проводился в монофракциях акцессорных хромшпинелидов из дунитов и верлитов массива. Химический состав хромшпинелидов определялся в Центре коллективного пользования «Изотопно-геохимические исследования» Института геохимии им. А.П. Виноградова Сибирского отделения Российской академии наук (ИГХ СО РАН).

Полированные препараты просматривались под микроскопом, и отбирались зерна хромшпинелидов, содержащие многофазные микровключения определённой формы, размера (10-30 мкм) и положения внутри зерна. Далее проводились высокотемпературные эксперименты по методике [14, 29]. Выбор температурного режима (1280-1300 $\left.{ }^{\circ} \mathrm{C}\right)$ определялся задачей перевести включения в расплавленное состояние, затем его закалить и полученное стекло проанализировать на рентгеновском микроанализаторе и сканирующем микроскопе.

Все экспериментальные исследования включений проводились в лаборатории геодинамики и магматизма Института геологии и минералогии им. В.С. Соболева СО РАН (ИГМ СО РАН, г. Новосибирск). Включения были изучены на электронном сканирующем микроскопе (СЭM) LEO 1430 VP (ИГМ СО РАН). Пределы обнаружения компонентов: 0,1-0,25 мас. \%. Составы включений и хромшпинелидов анализировались на рентгеновском микроанализаторе Camebax-Micro (ИГМ CO РАН). Пределы обнаружения (мас. \%) компонентов этим методом следующие: $\mathrm{SiO}_{2}-0,007, \mathrm{TiO}_{2}-$ 0,032, $\mathrm{Al}_{2} \mathrm{O}_{3}-0,011, \mathrm{Cr}_{2} \mathrm{O}_{3}-0,019, \mathrm{FeO}-0,019, \mathrm{MnO}$ - 0,034, $\mathrm{MgO}-0,011, \mathrm{CaO}-0,008, \mathrm{Na}_{2} \mathrm{O}-0,017$, $\mathrm{K}_{2} \mathrm{O}-0,009, \mathrm{Cl}-0,017, \mathrm{P}_{2} \mathrm{O}_{5}-0,011$. 
Для оценки РТ параметров кристаллизации ультраосновных пород массива Медек были использованы геотермобарометры, основанные на составах клинонопироксенов [30-34] и амфиболов [35-40].

Определение физико-химических параметров формирования массива проводилось с помощью обработки оригинальной информации по составам расплавных включений программными комплексами COMAGMAT [24-26] и PETROLOG [27].

\section{Составы минералов из верлитов массива Медек}

Оливины. В слабо измененных верлитах оливин образует идиоморфные и гипидиоморфные зерна, размером 2-3 мм, в серпентинизированных он сохранился только в виде реликтов. Изучение состава оливина по разрезу массива показало, что содержание форстеритового компонента варьирует от 88-90 до $73 \%$, при этом содержания $\mathrm{NiO}$ уменьшаются от $0,3-0,4$ до 0,1 мас. \%, а $\mathrm{MnO}$ увеличиваются от 0,1 до 0,4 мас. \% (табл. 1). Также сверху вниз по разрезу наблюдается уменьшение объемного содержания оливина с 98-96 до $65 \%$. Кроме того, вместо акцессорного хромшпинелида в виде включений в оливине появляется ильменит с низким содержанием $\mathrm{MgO}$.

Таблица 1. Представительные анализы оливинов из верлитов массива Медек

Table 1. Representative analyses of olivines from wehrlite of the Medek massif

\begin{tabular}{|c|c|c|c|c|c|c|c|c|}
\hline $\begin{array}{c}\text { Образец } \\
\text { Sample }\end{array}$ & $\mathrm{SiO}_{2}$ & $\mathrm{FeO}$ & $\mathrm{MnO}$ & $\mathrm{Mg0}$ & $\mathrm{Ni0}$ & $\begin{array}{c}\text { Cумма } \\
\text { Total }\end{array}$ & $\mathrm{Fo}$ & $\begin{array}{c}\text { Глубина } \\
\text { Depth }\end{array}$ \\
\hline $14-85$ & 39,30 & 12,70 & 0,20 & 47,50 & 0,20 & 99,90 & 87,00 & 386 \\
\hline $14-92$ & 40,60 & 14,30 & 0,30 & 44,20 & 0,30 & 99,70 & 84,70 & 429 \\
\hline $14-99$ & 40,30 & 13,80 & 0,30 & 45,70 & 0,30 & 100,40 & 85,50 & 456 \\
\hline $14-100$ & 40,00 & 14,10 & 0,30 & 44,40 & 0,30 & 99,10 & 84,90 & 457 \\
\hline $14-102$ & 40,20 & 15,20 & 0,20 & 45,10 & 0,30 & 101,00 & 84,10 & 471,4 \\
\hline $14-103$ & 39,10 & 18,10 & 0,40 & 42,20 & 0,20 & 100,00 & 80,60 & 483 \\
\hline $14-112$ & 38,50 & 22,70 & 0,30 & 37,70 & 0,10 & 99,30 & 74,80 & 517 \\
\hline
\end{tabular}

Примечание. Глубина - глубина отбора пробы из керна скважины, м; Fo- содержание форстеритового минала в оливине.

Note. Depth - the depth of sampling from the well core, $m$; Fo - the content of the forsterite component.

Клинопироксены чаще реликтовые, по составу отвечают субкальциевому авгиту $\left(\mathrm{Wo}_{42} \mathrm{En}_{52} \mathrm{Fs}_{3}\right)$ и диопсиду ( $\mathrm{Wo}_{49} \mathrm{En}_{48} \mathrm{Fs}_{3}$ ), с содержаниями $\mathrm{Al}_{2} \mathrm{O}_{3}-$ 0,1-1,8 мaс. \%, $\mathrm{Cr}_{2} \mathrm{O}_{3}$ - до 0,7 мас. \% (табл. 2).

Хролшпинелиды (в которых были найдены расплавные включения). Как показали проведенные нами ранее исследования ультраосновных комплексов [14], составы хромшпинелидов, содержащих расплавные включения и соответственно имеющих магматогенное происхождение, могут служить прямыми источниками сведений для петрологических построений. Поэтому особое внимание уделялось также и составу минералов-хозяинов. Проведенная оценка возможного влияния расплавных включений на состав хромшпинелидов продемонстрировала его полное отсутствие (табл. 3).
Таблииа 2. Представительные анализы клинопироксенов из верлитов массива Медек

Table 2. Representative analyses of clinopyroxenes from wehrlite of the Medek massif

\begin{tabular}{|c|c|c|c|c|c|c|c|c|c|}
\hline $\begin{array}{c}\text { Образец } \\
\text { Sample }\end{array}$ & $\mathrm{SiO}_{2}$ & $\mathrm{Al}_{2} \mathrm{O}_{3}$ & $\mathrm{Cr}_{2} \mathrm{O}_{3}$ & $\mathrm{FeO}$ & $\mathrm{MgO}$ & $\mathrm{CaO}$ & $\mathrm{Na}_{2} \mathrm{O}$ & $\begin{array}{c}\text { Cyмma } \\
\text { Total }\end{array}$ & En \\
\hline $14-95$ & 55,21 & 0,19 & н.о. & 2,02 & 17,09 & 25,28 & н.о. & 99,79 & 46,88 \\
\hline $14-96$ & 55,26 & 0,17 & н.о. & 2,03 & 17,41 & 25,43 & н.о. & 100,30 & 47,20 \\
\hline $14-97$ & 55,91 & 0,14 & н.о. & 1,93 & 17,29 & 25,37 & н.о. & 100,64 & 47,16 \\
\hline $14-93$ & 54,95 & н.о. & н.о. & 1,62 & 17,09 & 25,51 & н.о. & 99,17 & 46,96 \\
\hline $14-93$ & 55,15 & 0,11 & н.о. & 1,75 & 17,61 & 25,51 & 0,11 & 100,24 & 47,41 \\
\hline $14-93$ & 54,83 & 0,20 & 0,11 & 1,82 & 17,44 & 25,12 & 0,13 & 99,64 & 47,47 \\
\hline $14-93$ & 54,94 & 0,16 & н.о. & 1,75 & 17,59 & 25,35 & 0,11 & 100,01 & 47,54 \\
\hline $14-93$ & 54,63 & 0,10 & н.о. & 1,83 & 17,50 & 25,26 & 0,13 & 99,44 & 47,42 \\
\hline $14-99$ & 55,09 & н.о. & н.о. & 1,69 & 17,28 & 25,34 & 0,12 & 99,52 & 47,14 \\
\hline $14-99$ & 54,62 & 0,11 & н.о. & 1,82 & 17,25 & 25,29 & н.о. & 99,09 & 47,08 \\
\hline
\end{tabular}

Примечание. En - содержание энстатитового компонента; н.о. не определено.

Note. En - content of the enstatite component; H.o. - not determined.

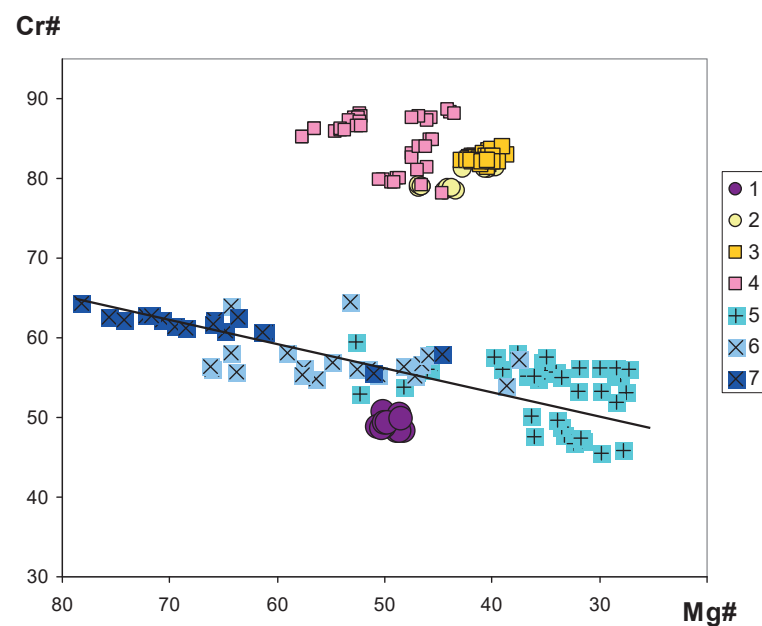

Puc. 2. Диаграмла Cr\#-Mg\# для хромшпинелидов из верлитов массива Медек (Восточный Саян). 1-7 - хромшпинелиды: из верлитов массива Медек (1); из дунитов Нижнетагильского массива, Урал (2); из дунитов Кондерского (3), Инаглинского (4) массивов; из дунитов Карашатского массива (5, офиолиты Южной Тувы ); из троктолитов района Сьерра-Леоне (6) и из перидотитов зоны разлома 1520' (7) в Центральной Атлантике. $\mathrm{Mg} \#=\mathrm{Mg} * 100 /\left(\mathrm{Mg}+\mathrm{Fe}^{2+}\right) . \mathrm{Cr} \#=\mathrm{Cr} * 100 /(\mathrm{Cr}+\mathrm{Al})$. Рисунок составлен на основе оригинальных данных с использованием материалов из работ [14, 29, 41]

Fig. 2. Diagram Cr\#-Mg\# for Cr-spinel from wehrlite of the Medek massif (East Sayan). 1-7 - Cr-spinel: from wehrite of the Medek massif (1); from dunites of the Nizhny Tagil massif, Ural (2); from dunites of the Konder (3), Inaglinsky (4) massifs; from dunites of the Karachat massif (5, ophiolites of the South Tuva); troctolites area Sierra Leone (6) and peridotites from the Fracture Zone $15^{\circ} 20^{\prime}$ (7) in the Central Atlantic. $\mathbf{M g} \#=M g * 100 /(\mathrm{Mg}+\mathrm{Fe} 2+) . \mathrm{Cr} \#=C r * 100 /(\mathrm{Cr}+\mathrm{Al})$. The figure is based on the original data using materials from the works $[14,29,41]$

Проведенные исследования показали умеренную хромистость (Cr\# до 50,7) рассмотренных хромшпинелидов, и по этому показателю они существенно отличаются от гораздо более хромистых минералов из ультрабазитов платиноносных массивов Сибирского кратона (Кондер и Инагли) и Урала 
Таблица 3. Представительные анализы хромшпинелидов из верлитов массива Медек

Table 3. Representative analyses of $\mathrm{Cr}$-spinel from wehrlite of the Medek massif

\begin{tabular}{|c|c|c|c|c|c|c|c|c|c|c|c|c|}
\hline Образец/Sample & $\mathrm{SiO}_{2}$ & $\mathrm{TiO}_{2}$ & $\mathrm{Al}_{2} \mathrm{O}_{3}$ & $\mathrm{Cr}_{2} \mathrm{O}_{3}$ & $\mathrm{FeO}$ & $\mathrm{MnO}$ & $\mathrm{MgO}$ & $\mathrm{CaO}$ & $\mathrm{Na}_{2} \mathrm{O}$ & $\mathrm{NiO}$ & Сумма/Total & $\mathrm{Cr} \#$ \\
\hline $2-2 \mathrm{~A} / 2$ & 0,06 & 0,16 & 27,93 & 38,74 & 22,89 & 0,16 & 10,67 & 0,02 & 0,05 & 0,03 & 100,70 & 48,20 \\
\hline $2-2 \mathrm{~A} / 3$ & 0,02 & 0,18 & 27,55 & 38,27 & 22,78 & 0,17 & 10,70 & 0,01 & 0,04 & 0,06 & 99,78 & 48,24 \\
\hline $2-2 \mathrm{~A} / 4$ & 0,02 & 0,24 & 27,70 & 38,44 & 22,66 & 0,18 & 10,67 & 0,02 & 0,04 & 0,06 & 100,02 & 48,21 \\
\hline $2-1-3 / 1$ & 0,05 & 0,27 & 25,88 & 39,66 & 22,95 & 0,20 & 10,95 & 0,10 & 0,05 & 0,08 & 100,17 & 50,69 \\
\hline $2-1-3 / 2$ & 0,04 & 0,32 & 26,98 & 38,43 & 22,69 & 0,14 & 11,17 & 0,03 & 0,06 & 0,07 & 99,92 & 48,86 \\
\hline $2-1-3 / 3$ & 0,03 & 0,22 & 27,36 & 38,78 & 22,78 & 0,13 & 11,06 & 0,02 & 0,04 & 0,08 & 100,52 & 48,74 \\
\hline $2-13 / 4$ & 0,02 & 0,26 & 27,33 & 38,58 & 22,90 & 0,19 & 11,09 & 0,03 & 0,04 & 0,08 & 100,54 & 48,64 \\
\hline $2-1-2 / 1$ & 0,05 & 0,33 & 26,21 & 39,58 & 22,95 & 0,15 & 10,64 & 0,03 & 0,03 & 0,08 & 100,04 & 50,32 \\
\hline $2-1-2 / 2$ & 0,01 & 0,23 & 26,83 & 38,83 & 23,18 & 0,15 & 10,99 & 0,02 & 0,03 & 0,08 & 100,36 & 49,26 \\
\hline $2-1-2 / 3$ & 0,03 & 0,23 & 26,83 & 38,99 & 22,94 & 0,19 & 10,93 & 0,02 & 0,04 & 0,04 & 100,22 & 49,36 \\
\hline $2-1-2 / 4$ & 0,05 & 0,35 & 26,30 & 38,87 & 23,59 & 0,20 & 10,59 & 0,08 & 0,03 & 0,13 & 100,18 & 49,79 \\
\hline
\end{tabular}

Примечание $/$ Note. $\mathrm{Cr} \#=C r * 100 /(\mathrm{Cr}+\mathrm{Al})$

(Нижнетагильский массив). При этом они хорошо согласуются с данными по хромитам из базит-гипербазитовых комплексов современных и древних (офиолиты) океанов (рис. 2). По соотношению хрома и железа изученные хромиты из верлита массива Медек наиболее соответствуют минералам из ультрабазитов Срединно-Атлантического хребта (CAX) в районе Сьерра-Леоне. По соотношению $\mathrm{TiO}_{2}-$ $\mathrm{Mg} \#$ они наиболее близки к хромитам из дунитов Карашатского массива (офиолиты Южной Тувы). Необходимо отметить, что хромшпинелиды из рассмотренных базит-ультрабазитовых пород современных (Срединно-Атлантический хребет) и древних (Карашатский массив) океанических структур содержат расплавные включения и, соответственно, имеют магматогенное происхождение [29, 41].

\section{Расплавные включения в хромшпинелидах из верлитов массива Медек}

Было установлено, что хромшпинелиды из всех изученных проб содержат микровключения, которым присущи некоторые признаки, характерные для расплавных включений. При тщательном просмотре выяснилось, что «включения» в хромитах из дунитов и части верлитов обладают очень невыдержанными формами и разнообразным содержимым, без характерных пузырьков газа, что не позволяет их использовать для дальнейшего физико-химического моделирования. В единственном образце, в хромшпинелидах из верлита, найденные силикатные включения по внешним признакам и химическому составу соответствовали включениям расплавов.

Исследования на СЭМ показали, что прогретые силикатные включения содержат флюидный пузырек, располагающийся в гомогенной среде и имеющий почти всегда фактически эталонную круглую форму (рис. 3, А, Б). Такого рода равновесные формы флюидных включений являются характерным признаком расплавных, которые при нагреве и быстром охлаждении превратились в стекло. Соотношение объемов флюидных пузырьков и включений свидетельствует о существенном содержании летучих компонентов в магматических системах.

В зависимости от количества внутренних фаз включения подразделяются на две группы: 1) со стеклом и флюидным пузырьком (рис. $3, \mathrm{~A}$, Б) и
2) со стеклом, пузырьком и кристаллическими фазами (рис. 3, В, Г). Кристаллические фазы представляют собой реликты высокомагнезиального тугоплавкого оливина, вокруг которого в одном случае (на пример № 4 на рис. 3, В) образуется кайма, а в другом (№ 3 на рис. 3, Г) он обрастает со всех сторон новообразованными микрокристаллическими фазами. В обоих случаях светлые микрокристаллики образуют фактически структуру спинифекс (рис. 3, В, Г), сформировавшуюся практически мгновенно во время закалки микроконтейнера с пробой в воде. Кроме игольчататой, новообразованные кристаллы иногда приобретают изометричную форму (№ 4 на рис. 3 , Г), и по данным количественного анализа (табл. 4) находятся ближе всего к высоко титанистому амфиболу - керсутиту (субкальциевый субкремнистый ферро-керсутит) [40]. В то же время недоплавленные оливины во включениях имеют высокие значения форстеритового компонента, сравнимые с данными по оливинам из дунитов Медекского массива.

Таблица 4. Представительные анализы кристаллических фаз в прогретых включениях в хромшпинелидах из верлитов массива Медек

Table 4. Representative analyses of crystal phases in heated inclusions in the Cr-spinel from wehrlite of the Medek massif

\begin{tabular}{|c|c|c|c|c|c|c|}
\hline Образец/Sample & 1 & 2 & 3 & 4 & 5 & 6 \\
\hline $\mathrm{SiO}_{2}$ & 41,25 & 40,74 & 40,45 & 40,43 & 32,32 & 30,57 \\
\hline $\mathrm{TiO}_{2}$ & н.о. & н.о. & н.о. & н.о. & 18,6 & 19,51 \\
\hline $\mathrm{Al}_{2} \mathrm{O}_{3}$ & н.о. & н.о. & н.о. & н.о. & 8,23 & 7,43 \\
\hline $\mathrm{Cr}_{2} \mathrm{O}_{3}$ & 1,01 & 1,02 & 1,02 & 1,23 & 1,4 & 1,17 \\
\hline $\mathrm{Fe} 0$ & 7,87 & 8,99 & 10,45 & 10,09 & 16,49 & 17,99 \\
\hline $\mathrm{MnO}$ & н.о. & н.о. & н.о. & н.о. & н.о. & 0,33 \\
\hline $\mathrm{MgO}$ & 49,46 & 48,79 & 47,46 & 47,99 & 7,91 & 11,06 \\
\hline $\mathrm{CaO}$ & н.о. & н.о. & 0,19 & 0,26 & 10,84 & 8,59 \\
\hline $\mathrm{Na} 20$ & н.о. & н.о. & н.о. & н.о. & 1,24 & 1,33 \\
\hline $\mathrm{K}_{2} \mathrm{O}$ & н.о. & н.о. & н.о. & н.о. & 0,15 & н.о. \\
\hline $\mathrm{NiO}$ & 0,42 & 0,47 & 0,42 & н.о. & н.о. & н.0. \\
\hline Сумма/Total & 100,01 & 100,01 & 99,99 & 100 & 97,18 & 97,98 \\
\hline Fo & 91,42 & 90,2 & 88,4 & 89,14 & - & - \\
\hline
\end{tabular}

Прилечание. 1-4-оливин; 5, 6 - кристаллические фазы, близкие по химическому составу к алфиболам (керсутитам); н.о. - не определено.

Note. 1 -4 are the olivine; 5, 6 are the crystalline phases similar in chemical composition of the amphiboles (kaersutite); H.o. - not determined. 

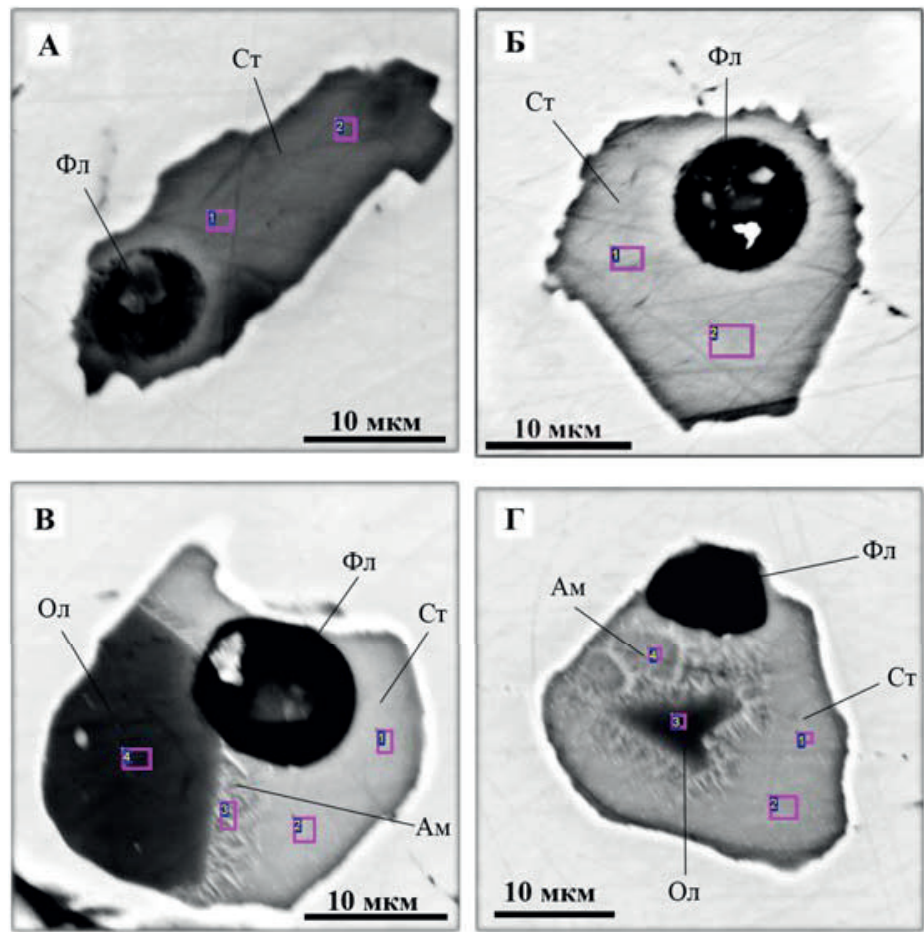

Рис.3. Первичные силикатные микровключения в хромшпинелидах из верлитов массива Медек (после высокотемпературных опытов и закалки): $A$ - первичное двухфазное расплавное включение первого типа после высокотемпературного эксперимента и закалки; $\boldsymbol{B}$ - двухфазное расплавное включение второго типа после высокотемпературного эксперимента и закалки; $\boldsymbol{B}, \boldsymbol{\Gamma}$ - расплавные включения с недоплавленныли и новообразованныли кристаллическими фазами после высокотемпературных экспериментов и закалки. Сканирующий микроскоп. Отмечены участки анализов. Фл - флюидный пузырек; Сm - гомогенное силикатное стекло; Ол-недоплавленные реликты оливина; Ам - новообразованные микрокристаллиты амфибола

Fig. 3. Primary silicate micro-inclusions in Cr-spinel from wehrlite of the Medek massif (after high-temperature experiment and quenching): $A$ - primary two-phase melt inclusion of the first type after high-temperature experiment and quenching; $\boldsymbol{B}$ - two-phase melt inclusion of the second type after high-temperature experiment and quenching; $\boldsymbol{B}, \boldsymbol{G}$ - melt inclusions with under-melted and newly formed crystalline phases after high-temperature experiments and quenching. Scanning microscope. Marked areas of analysis. $\Phi_{л}-$ fluid bubble; $\mathrm{Cm}$-homogeneous silicate glass; $\mathrm{O} \pi$ - under-melted relicts of olivine; Am - newly formed amphibole microcrystallites

Описанные выше особенности соотношений различных фаз, заполняющих расплавные включения, сформировались в ходе высокотемпературных экспериментов, в результате которых в зависимости от продолжительности происходило полное расплавление содержимого или (при недостатке времени, а также, возможно, и температуры) оставались реликты оливина, обраставшие при закалке новыми фазами.

В одном случае содержимое включений было полностью расплавлено и при закалке образовались только две фазы: стекло (закаленный силикатный расплав) и флюидный пузырек. В других случаях времени (и возможно температуры) экспериментов, по всей вероятности, не хватило для полного расплавления содержимого включений и внутри остались недоплавленные кристаллики оливина, на которые в ходе закалки нарастали новообразованные кристаллические фазы. Это позволяет сделать вывод, что для реконструкции физико-химических параметров реальной магматической системы необходимо использовать результаты изучения стекол двухфазовых включений.
Составы расплавов, участвовавших в формировании верлитов массива Медек

Количественный анализ на сканирующем электронном микроскопе и на микрозонде стекол из прогретых и закаленных двухфазных расплавных включений (стекло + круглый флюидный пузырек) в хромшпинелидах показал наличие двух типов силикатных расплавов (табл. 5).

Расплавные включения первого типа обладают нормальной щелочностью, и по соотношению суммы $\mathrm{Na}_{2} \mathrm{O}+\mathrm{K}_{2} \mathrm{O}$ (до 1.6 мас. \% ) и содержаний $\mathrm{SiO}_{2}$ относятся к толеитовой серии, что характерно также для включений в хромшпинелидах из базит-ультрабазитовых комплексов САХ и офиолитов Южной Тувы $[29,41]$. Однако, сравнивая их состав с уровнем содержаний щелочей во включениях из хромитов массива Кондёр [14, 21], можно отметить, что последним присущи более высокие величины содержаний $\mathrm{K}_{2} \mathrm{O}$.

По уровню содержаний $\mathrm{MgO}(10,5-13,4$ мас. \% ) и $\mathrm{SiO}_{2}(44,8-46,5$ мас. \%) включения этого типа располагаются на границе полей оливиновых базальтов и пикробазальтов (рис. 4), наиболее близки к ним по соотношению этих элементов сте- 
Таблица 5. Представительные анализы стекол прогретых включений в хромшпинелидах из верлитов массива Медек

Table 5. Representative analyses of glasses of heated inclusions in Cr-spinel from wehrlite of the Medek massif

\begin{tabular}{|c|c|c|c|c|c|c|c|c|c|c|c|c|c|}
\hline № & Образец/Sample & $\mathrm{SiO}_{2}$ & $\mathrm{TiO}_{2}$ & $\mathrm{Al}_{2} \mathrm{O}_{3}$ & $\mathrm{Cr}_{2} \mathrm{O}_{3}$ & $\mathrm{FeO}$ & $\mathrm{MnO}$ & $\mathrm{MgO}$ & $\mathrm{CaO}$ & $\mathrm{Na}_{2} \mathrm{O}$ & $\mathrm{K}_{2} \mathrm{O}$ & $\mathrm{P}_{2} \mathrm{O}_{5}$ & Сумма/Total \\
\hline 1 & $2 \mathrm{~A}-2$ & 46,14 & 0,87 & 13,36 & 1,18 & 9,47 & 0,11 & 13,36 & 14,96 & 1,18 & 0,27 & 0,06 & 100,96 \\
\hline 2 & $2 \mathrm{~A}-2 / 1$ & 45,79 & 0,91 & 13,74 & 1,23 & 9,59 & 0,15 & 10,68 & 16,26 & 1,30 & 0,25 & 0,05 & 99,95 \\
\hline 3 & $2 \mathrm{~A} 2 / 2$ & 45,90 & 0,98 & 13,55 & 1,38 & 9,44 & 0,11 & 11,41 & 15,86 & 1,15 & 0,27 & 0,03 & 100,07 \\
\hline 4 & $2 \mathrm{~A}-2 / 4$ & 45,87 & 0,96 & 13,37 & 1,26 & 9,47 & 0,17 & 11,08 & 15,99 & 1,27 & 0,27 & 0,06 & 99,77 \\
\hline 5 & $2 \mathrm{~A}-2 / 5$ & 46,42 & 0,89 & 13,62 & 1,37 & 9,16 & 0,18 & 11,86 & 15,64 & 1,16 & 0,25 & 0,05 & 100,60 \\
\hline 6 & $2-2 \mathrm{~A} / 7$ & 45,58 & 0,88 & 13,65 & 1,18 & 9,00 & 0,12 & 11,19 & 15,39 & 1,27 & 0,28 & 0,07 & 98,60 \\
\hline 7 & $2-2 \mathrm{~A} / 8$ & 45,80 & 0,85 & 13,23 & 1,39 & 9,28 & 0,09 & 11,05 & 15,43 & 1,21 & 0,26 & 0,06 & 98,66 \\
\hline 8 & $2-2 \mathrm{~A} / 9$ & 46,54 & 0,96 & 13,75 & 1,22 & 9,07 & 0,10 & 10,45 & 15,86 & 1,19 & 0,27 & 0,07 & 99,48 \\
\hline 9 & $2-2 \mathrm{a}-2 / 1$ & 45,63 & 0,82 & 13,68 & 1,28 & 10,44 & н.0. & 10,54 & 16,06 & 1,26 & 0,30 & н.0. & 100,01 \\
\hline 10 & $2-2 \mathrm{a}-2 / 2$ & 44,79 & 0,85 & 13,02 & 1,82 & 10,41 & н.0. & 11,46 & 16,08 & 1,23 & 0,35 & н.0. & 100,01 \\
\hline 11 & $2-1-2 / 1$ & 32,74 & 3,86 & 6,69 & 1,73 & 21,16 & 0,39 & 9,44 & 19,68 & 0,36 & 0,02 & 2,24 & 98,31 \\
\hline 12 & $2-1-2 / 2$ & 32,43 & 3,78 & 6,75 & 1,98 & 20,87 & 0,36 & 9,29 & 19,87 & 0,34 & 0,02 & 2,27 & 97,96 \\
\hline 13 & $2 .-1-2 / 1$ & 32,79 & 3,71 & 6,61 & 1,79 & 23,24 & 0,45 & 9,14 & 20,08 & н.0. & н.0. & 2,20 & 100,01 \\
\hline 14 & $2 .-1-2 / 2$ & 32,47 & 3,48 & 6,86 & 1,83 & 23,49 & 0,43 & 9,07 & 20,17 & н.0. & н.0. & 2,21 & 100,01 \\
\hline 15 & $2-1-3 / 1$ & 31,95 & 4,01 & 6,67 & 1,97 & 21,67 & 0,36 & 9,38 & 19,55 & 0,37 & 0,03 & 2,17 & 98,13 \\
\hline 16 & $2-3-1 / 2$ & 32,60 & 3,87 & 6,85 & 1,69 & 21,57 & 0,37 & 9,32 & 19,42 & 0,35 & 0,02 & 2,17 & 98,23 \\
\hline 17 & $2 .-1-3 / 1$ & 32,76 & 3,70 & 6,75 & 1,50 & 23,37 & 0,47 & 8,88 & 19,86 & 0,43 & н.0. & 2,29 & 100,01 \\
\hline 18 & $2 .-1-3 / 2$ & 32,72 & 3,71 & 6,87 & 1,68 & 23,37 & 0,44 & 8,91 & 20,00 & 0,22 & н.0. & 2,09 & 100,01 \\
\hline
\end{tabular}

Примечание. 1-10 - включения первого типа; 11-18 - включения второго типа; н.о. - не определено.

Note. 1-10 are the inclusions of the first type; 11-18 are the inclusions of the second type; H.o. - not determined.

кла из расплавных включений Нижнетагильского и, в меньшей степени, Карашатского массивов.

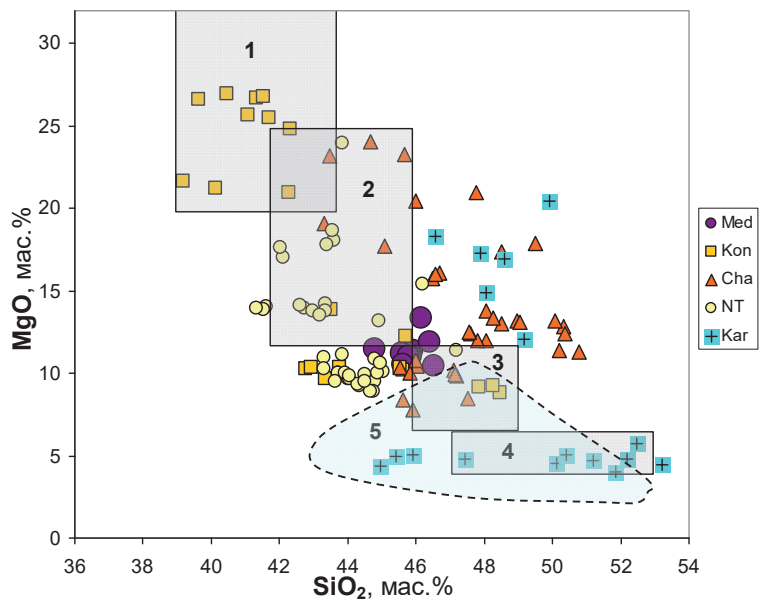

Puc. 4. Диагралма $\mathrm{MgO}-\mathrm{SiO}_{2}$ для стекол двухфазных (после высокотемпературных экспериментов) включений первого типа в хромшпинелидах из верлитов массива Медек. Сте кла расплавных включений в хромшпинелидах: из верли тов массива Медек (Med); из дунитов Кондерского (Kon), Чадского (Cha), Нижнетагильского (NT) и Карашатско го (Kar) массивов. Поля по [42]: 1 - пикриты, 2- пикробазальты, 3 - оливиновые базальты, 4 - базальты, 5 - сте кла расплавных включений в хролшпинелидах из троктолитов района Сьерра-Леоне (Срединно-Атлантический хребет ). Рисунок составлен на основе оригинальных данных с использованием материалов из работ [14, 29, 41]

Fig. 4. $\mathrm{MgO}-\mathrm{SiO}_{2}$ diagram for glass of two-phase (after high-temperature experiments) inclusions of the first type in $\mathrm{Cr}$-spinel from wehrlite of the Medek massif. Glass of melt inclusions in $\mathrm{Cr}$-spinel: from wehrlite of the Medic massif (Med); from dunite Conder (Kon), Chad (Cha), Nizhny Tagil (NT) and Karashat (Kar) massifs. Fields: 1 - picrites, 2 - picrobasalts, 3 - olivine basalts, 4 - basalts, 5 - glass of melt inclusions in chrome spinel from troctolite of Sierra Leone (Mid-Atlantic ridge). The figure is based on the original data using materials from the works $[14,29,41]$

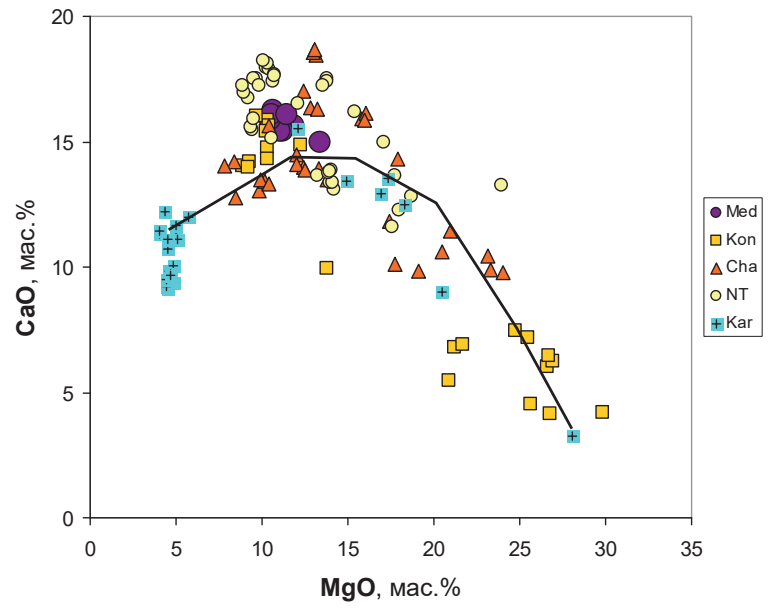

Puc. 5. Соотношение $\mathrm{CaO}-\mathrm{MgO}$ в составах стекол двухфазных (после высокотемпературных экспериментов) включений первого типа в хромшпинелидах из верлитов массива Медек

Fig. 5. $\mathrm{CaO}-\mathrm{MgO}$ ratio in compositions of glass of two-phase (after high-temperature experiments) inclusions of the first type in Cr-spinel from wehrlite of the Medek massif

C помощью диаграмм, показывающих зависимость значений химических компонентов в расплавных включениях в хромитах от $\mathrm{MgO}$, можно выяснить особенности эволюции магматических систем при кристаллизации расслоенных базит-ультрабазитовых плутонов. Подобная ситуация была нами рассмотрена на примере Карашатского базитультрабазитового массива [41]. Составы включений в хромитах целого ряда массивов трассируют путь последовательной внутрикамерной кристаллизации расплавов (рис. 5), что характерно и для расплавных включений этого типа в массиве Медек. При этом точки их составов находятся в тесной ассоциации с данными по породам верлит-клинопироксенит-габбровой серии Карашатского массива. Та- 

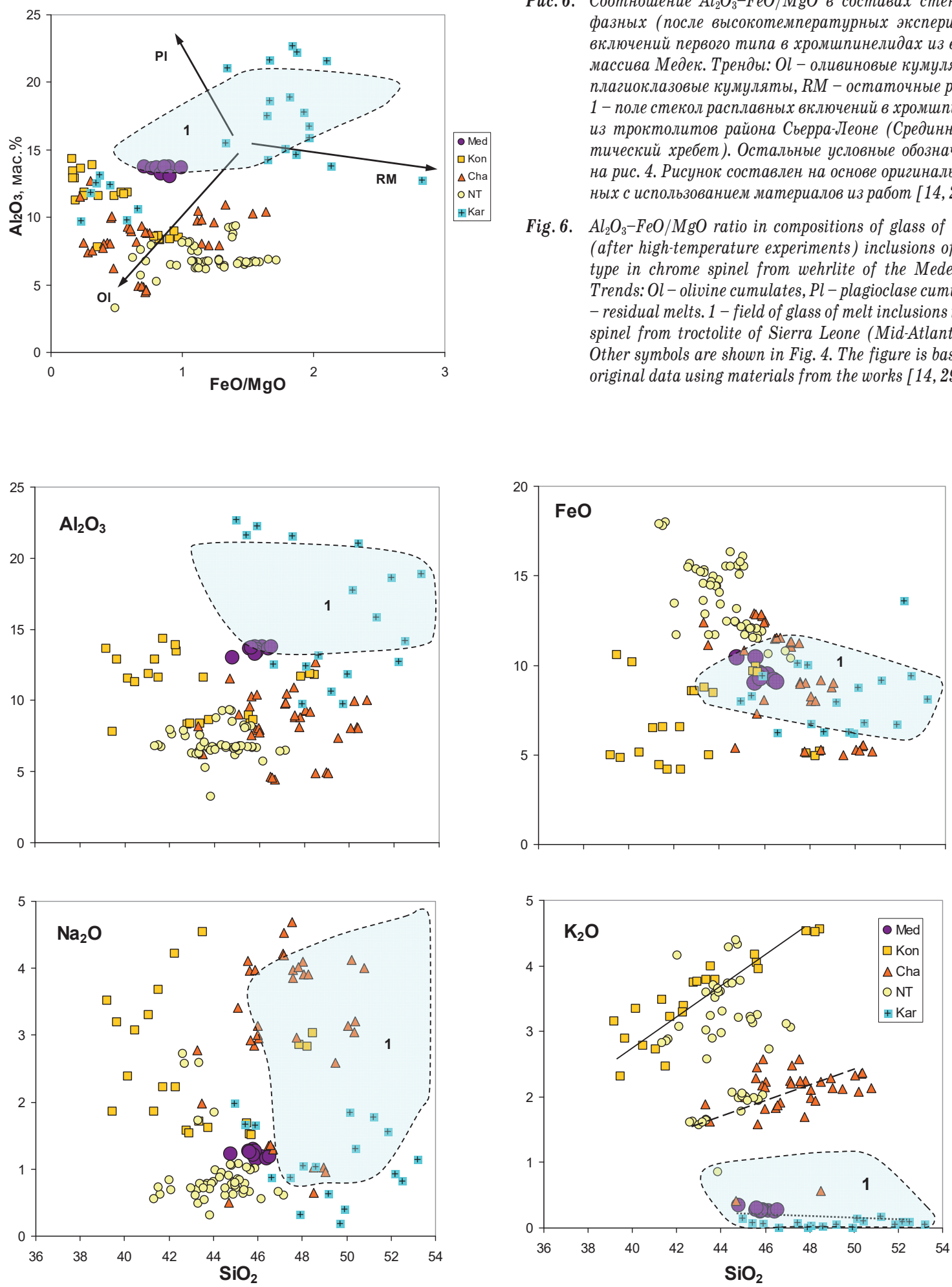

Puc. 6. Соотношение $\mathrm{Al}_{2} \mathrm{O}_{3}-\mathrm{FeO} / \mathrm{MgO}$ в составах стекол двухфазных (после высокотелпературных эксперилентов) включений первого типа в хромшпинелидах из верлитов массива Медек. Тренды: $\mathrm{Ol}$ - оливиновые кулуляты, $\mathrm{Pl}$ плагиоклазовые кумуляты, RM - остаточные расплавы. 1 - поле стекол расплавных включений в хролшпинелидах из троктолитов района Сьерра-Леоне (Срединно-Атлантический хребет). Остальные условные обозначения сл. на рис. 4. Рисунок составлен на основе оригинальных данных с использованием материалов из работ [14, 29, 41]

Fig. 6. $\mathrm{Al}_{2} \mathrm{O}_{3}-\mathrm{FeO} / \mathrm{MgO}$ ratio in compositions of glass of two-phase (after high-temperature experiments) inclusions of the first type in chrome spinel from wehrlite of the Medek massif. Trends: Ol-olivine cumulates, $P l$ - plagioclase cumulate, $R M$ - residual melts. 1 - field of glass of melt inclusions in chrome spinel from troctolite of Sierra Leone (Mid-Atlantic ridge). Other symbols are shown in Fig. 4. The figure is based on the original data using materials from the works [14, 29, 41]

Pис. 7. Вариационные диаграмлы (мас.\%) для стекол двухфазных (после высокотемпературных экспериментов) включений первого типа в хролшпинелидах из верлитов массива Медек. 1 - поле стекол расплавных включений в хромшпинелидах из троктолитов района Сьерра-Леоне (Срединно-Атлантический хребет). Остальные условные обозначения см. на рис. 4. Рисунок составлен на основе оригинальных данных с использованием материалов из работ [14, 29, 41]

Fig. 7. Variation diagrams (wt.\%) for glasses of two-phase (after high-temperature experiments) inclusions of the first type in Cr-spinel from wehrlite of the Medek massif. 1 - field of glass of melt inclusions in Cr-spinel from troctolite of Sierra Leone (Mid-Atlantic ridge). Other symbols are shown in Fig. 4. The figure is based on the original data using materials from the works [14, 29, 41] 
кая же картина наблюдается и на диаграмме $\mathrm{Al}_{2} \mathrm{O}_{3}$ и $\mathrm{FeO} / \mathrm{MgO}$, где фигуративные точки составов включений первого типа лежат недалеко от линии тренда, характерного для оливиновых кумулатов, и тесно ассоциируют с полями составов включений из троктолитов района Сьерра-Леоне (рис. 6).

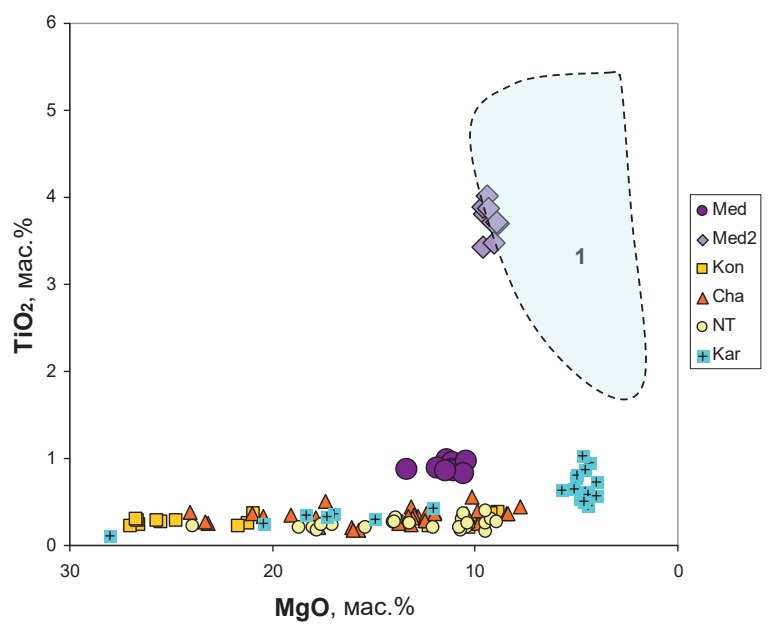

Pис. 8. Содержания титана в стеклах двухфазных (после высо котемпературных экспериментов) включений второго типа в хромшпинелидах из верлитов массива Медек. Стекла расплавных включений в хролшпинелидах: из верлитов массива Медек (первый тип - Med, второй mun - Med2); из дунитов Кондерского (Kon), Чадского (Сhа), Нижнетагильского (NT) и Карашатского (Kar) массивов. 1 - поле стекол расплавных включений в хромшпинелидах из троктолитов района Сьерра-Леоне (Срединно-Атлантический хребет). Рисунок составлен на основе оригинальных данных с использованием мате риалов из работ $[14,29,41]$

Fig. 8. Content of titanium in glasses of two-phase (after high-temperature experiments) inclusions of the second type in Cr-spinel from wehrlite of the Medek massif. Glass of melt inclusions in Cr-spinel from wehrlite of the Medek massif ( first type-Med, the second type-Med2); from dunites of the Konder (Kon), Chad (Cha), Nizhny Tagil (NT) and Karachat (Kar) massifes. 1 - the field of glass of melt inclusions in $\mathrm{Cr}$ spinel from troctolite of Sierra Leone (Mid-Atlantic ridge). The figure is based on the original data using materials from the works [14, 29, 41]

На других вариационных диаграммах (рис. 7) стекла включений первого типа наиболее близки по основным петрохимическим компонентам $\left(\mathrm{SiO}_{2}, \mathrm{Al}_{2} \mathrm{O}_{3}, \mathrm{FeO}, \mathrm{Na}_{2} \mathrm{O}, \mathrm{K}_{2} \mathrm{O}\right)$ к данным по расплавным включениям в хромшпинелидах из пород океанических структур - Карашатский массив (офиолиты Южной Тувы) и район Сьерра-Леоне (Срединно-Атлантический хребет). Особенно это хорошо видно по соотношению $\mathrm{K}_{2} \mathrm{O}-\mathrm{SiO}_{2}$, когда расплавные включения в хрошпинелидах массива Медек, офиолитов Южной Тувы и Срединно-Атлантического хребта образуют единый низкокалиевый (менее $1 \%$ ) тренд, в отличие от включений из платиноносных массивов, обладающих явно повышенными содержаниями $\mathrm{K}_{2} \mathrm{O}$ (рис. 7). Эти данные позволяют сделать вывод о том, что образование верлитов происходило при участии низкокалиевых пикробазальтовых расплавов нормальной щелочности, наиболее близких по петрохимическим характеристикам к данным по расплавным включениям в хромитах из океанических комплексов.

В то же время наличие многофазных включений с недоплавленными кристалликами оливина свидетельствует в пользу предположения, что исходная магма для пород массива была более магнезиальной, чем пикробазальтовый расплав. Исходя из этого нами был рассчитан предполагаемый состав первичного расплава для пород массива $\mathrm{Me}^{-}$ дек [22], который по уровню содержаний $\mathrm{SiO}_{2}$ (45 мac. \% ) и $\mathrm{MgO}(18$ мас. \% ) отвечает пикритовому.

Расплавные включения второго типа. Фазовый состав и морфология (рис. 3 , Б) расплавных включений второго типа идентичны таковым первого. Главные отличия заключаются в особенностях химического состава, а именно: высоких содержаниях $\mathrm{TiO}_{2}$ (макс. 3,7 мас. \%), $\mathrm{FeO}$ (макс. 23,5 мас. $\%$ ), $\mathrm{P}_{2} \mathrm{O}_{5}$ (макс. 2,3 мас. \%), при этом средние содержания $\mathrm{SiO}_{2}$ составляют всего 32,6 мас. \%. Полные аналоги магматических пород и расплавных включений такого состава нам не известны. Кроме того, наблюдаемые соотношения компонентов во включениях этого типа вряд ли могут соответствовать составу расплава, из которого осаждались изученные хромшпинелиды. Однако возможность существования таких, по сути, рудоносных расплавов подтверждается результатами изучения Fe-Ti интрузивных комплексов Центральной Атлантики [29] (рис. 8).

\section{Эволюция физико-химических условий кристаллизации расплавов при формировании массива Медек}

Основой для выяснения особенностей эволюции физико-химических условий кристаллизации магматических систем массива Медек являются исследования расплавных включений в хромшпинелидах из верлитов. В то же время к решению генетических задач привлекались и другие методы, включая минералогические термометры и барометры, а также расчетное моделирование, так как только согласованные результаты различных методик могут послужить наиболее обоснованными выводами об условиях кристаллизации пород.

Прежде всего, наличие первичных силикатных расплавных включений в хромшпинелидах (и преобразование их содержимого после высокотемпературных опытов в равновесную систему гомогенное стекло + круглый флюидный пузырек) прямо свидетельствует о том, что рассмотренные верлиты массива Медек формировались из расплавов. Данные по стеклам прогретых включений (с содержанием магния до 13,4 мас. \%), близкие к пикробазальтовым магмам, позволили рассчитать возможный состав исходного пикритоидного расплава (с $\mathrm{MgO}$ - 17,85 мас. \%) для массива Медек [22]. Именно эти составы расплавов послужили в дальнейшем основой для расчетов условий кристаллизации рассмотренных верлитов. 
Как было отмечено выше, основой для решения генетических задач послужили данные по расплавным включениям. При этом дополнительную и весьма важную информацию удалось получить с помощью минералогических термометров и барометров. В частности, на основе составов клинопироксенов были рассчитаны с использованием минералогических термометров и барометров [31-33] PТ параметры кристаллизации верлитов массива $\mathrm{Me}$ дек: около $1255{ }^{\circ} \mathrm{C}$ при давлении 2,3-5,9 кбар. Очень полезную информацию несут находящиеся в расплавных включениях в хромшпинелидах микрокристаллики амфиболов (рис. $3, \mathrm{~B}$, Г), опираясь на составы которых, по минералогическому барометру [36], удалось оценить давление: 3,2-4,2 кбар.

Температуры кристаллизации верлитов были получены в результате численного моделирования в программном комплексе PETROLOG [27]. Основой для расчетов послужили составы стёкол включений первого типа, граничные условия соответствовали давлению 4 кбар (установлено по усредненным оценкам по пироксеновым и амфиболовым геобарометрам), $\mathrm{H}_{2} \mathrm{O}-0,5 \%$, расчетная величина хромистости хромшпинелида корректировалась по реальным значениям и составила $48,2 \%$. Исходя из этого, было установлено, что температура кристаллизации оливинов снижалась от 1275 до $1240{ }^{\circ} \mathrm{C}$, хромшпинелиды формировались в диапазоне $1260-1240{ }^{\circ} \mathrm{C}$, а клинопироксены $1235-1220^{\circ} \mathrm{C}$, данные по которым хорошо согласуются с оценками по геотермометру.

Расчеты условий кристаллизации расплавов по программе COMAGMAT [24, 25] проведены на основе данных по составам расплавных включений первого типа в хромшпинелидах из верлита и с учетом результатов использования минералогических термометров и барометров.

Равновесная кристаллизаиия возможного исходного расплава (с $\mathrm{MgO}-17,85$ мас. \%) в ходе декомпрессии от 10 кбар (низы коры) до 2 кбар. Буфер QFM. Содержание воды - 0,5 мас. \% . Расчеты показали широкие диапазоны возможных давлений кристаллизации минералов из верлитов массива Медек. В то же время данные по реальным составам оливинов $\left(\mathrm{Fo}_{0}=80,6-85,5\right)$ и клинопироксенов $(E n=46,8-47,6)$ верлитов этого массива в ходе анализа результатов расчетного моделирования позволили уточнить давления при кристаллизации оливинов $(2,6-4,9$ кбар) и клинопироксенов (2,9-3,6 кбар). Обращают на себя внимание перекрывающиеся в значительной мере диапазоны давлений при формировании этих двух минералов, а также сходство с оценками по пироксеновым и амфиболовым барометрам.

Расчеты фракиионной кристаллизации того же исходного расплава (с $\mathrm{MgO}$ - 17,85 мас. \%) при тех же условиях (в ходе декомпрессии от 10 кбар до 2 кбар; буфер QFM; $\mathrm{H}_{2} \mathrm{O}$ - 0,5 мас. \% ) показали реальные максимальные давления (с учетом составов минералов) для оливина - до 4,9 кбар, и для клинопироксена - до 4,2 кбар, что подтверждает результаты равновесной кристаллизации и минералогических барометров.

Таким образом, проведенные расчеты по различным минералогическим барометрам и по различным моделям кристаллизации на основе составов расплавных включений показали, что давление при формировании верлитов массива Медек было около 4 кбар (в среднем 2,8-4,7 кбар).

Терлолетрия равновесий минерал-расплав. Изобарическая система - 4 кбар (согласно оценкам по минералогическим барометрам и равновесной декомпрессионной кристаллизации). Буфер QFM. Состав магмы - стекло расплавных включений пикробазальтового состава $(\mathrm{MgO}-13,36$ мас. \%) и рассчитанный состав исходного расплава $(\mathrm{MgO}-$ 17,85 мас. \%). Содержание воды - 0,5 мас. \%. В результате для исходного пикритоидного расплава определены следующие температуры равновесия: оливин $-1380{ }^{\circ} \mathrm{C}$, клинопироксен $-1270{ }^{\circ} \mathrm{C}$. В случае пикробазальтового расплава: оливин $1300{ }^{\circ} \mathrm{C}$, клинопироксен $-1240{ }^{\circ} \mathrm{C}$. Обращает на себя внимание соответствие рассчитанных в случае пикробазальтового расплава (данные по составу расплавных включений) температур кристаллизации клинопироксена с данными по пироксеновому термометру и по результатам расчетов с помощью программы PETROLOG [27].

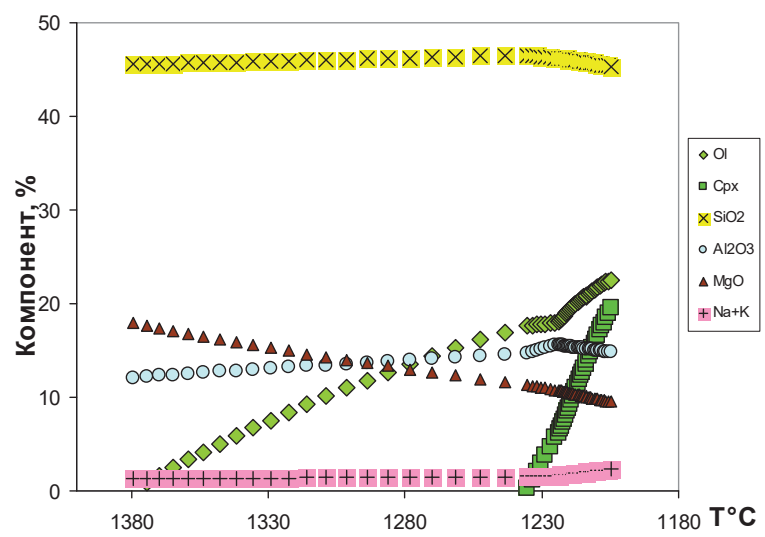

Pис.9. Фракиионная кристаллизация исходного расплава ( $\mathrm{MgO}$ - 17,85 мас.\%) для массива Медек. Компонент, \% изменения содержаний минералов (Ol - оливин, Срх клинопироксен) и химических компонентов $\left(\mathrm{Na}+\mathrm{K}=\mathrm{Na}_{2} \mathrm{O}+\mathrm{K}_{2} \mathrm{O}\right.$, мас. \%) в расплаве при снижении температуры. Расчетное моделирование с помощью програмлы COMAGMAT [25, 26]

Fig. 9. Fractional crystallization of the initial melt (MgO 17,85 wt.\%) for the Medek massif. Component, \% - changes in mineral content (Ol-olivine, $\mathrm{Cpx}$ - clinopyroxene) and chemical components $\left(\mathrm{Na}+\mathrm{K}=\mathrm{Na}_{2} \mathrm{O}+\mathrm{K}_{2} \mathrm{O}\right.$, wt.\%) in the melt with decreasing temperature. Computational modeling using COMAGMAT [25, 26]

Расчеты фракиионной кристаллизации исходного расплава ( $\mathrm{MgO}$ - 17,85 мас. \%) при тех же условиях (в изобарической системе -4 кбар. Буфер QFM. Содержание воды - 0,5 мас. \%) показали, что оливин начинает кристаллизоваться при $1375{ }^{\circ} \mathrm{C}$ (совпадает с данными по равновесию $\left.1380{ }^{\circ} \mathrm{C}\right)$. Процессы снижения температуры и роста 
количества оливина происходят относительно быстро - до $1235{ }^{\circ} \mathrm{C}$, когда начинает кристаллизоваться клинопироксен (рис. 9). Далее интенсивно растет клинопироксен и скорость его накопления превышает кристаллизацию оливина практически в четыре раза - идет формирование верлита. Таким образом, мы видим, что дуниты массива Медек формируются начиная с $1380{ }^{\circ} \mathrm{C}$, а верлиты образуются при более низких температурах $1235{ }^{\circ} \mathrm{C}$.

Одновременно с кристаллизацией оливина и клинопироксена закономерно изменяется состав остаточного расплава: падает $\mathrm{MgO}$, растет количество щелочей. Интересно поведение $\mathrm{SiO}_{2}$ - с началом кристаллизации клинопироксена рост этого компонента сменяется падением при снижении температуры. Фактически проявляется реверсивный тренд, хорошо выделяющийся на диаграмме $\mathrm{MgO}-\mathrm{SiO}_{2}$ (рис. $10, \mathrm{~A}$ ) и отмеченный нами при изучении расплавных включений в хромшпинелидах из пород других ультраосновных массивов [21]. Очень важным является факт расположения составов расплавных включений вдоль расчетных трендов изменения состава расплава (рис. 10, А, Б), то есть здесь экспериментальные данные по включениям с одной стороны подтверждают достоверность проведенных расчетов, а с другой - такое соотношение показывает, что включения не являются случайностью, а фиксируют закономерную и теоретически обоснованную эволюцию расплава.

На диаграмме $\mathrm{CaO}-\mathrm{MgO}$ (рис. 10, Б) точки составов стекол расплавных включений приурочены в основном к изгибу тренда изменения состава расплава, который практически совпадает с магнезиальной ветвью тренда расплавных включений в хромшпинелидах из дунитов Карашатского массива (Южная Тува).
Расчеты фракционной кристаллизации пикробазальтового расплава (состав стекла расплавного включения с максимальным $\mathrm{MgO}$ 13,36 мас. \%) в изобарической системе (4 кбар. Буфер QFM. Содержание воды - 0,5 мас. \% ) показывают, что оливин начинает кристаллизоваться около $1275{ }^{\circ} \mathrm{C}$, но количество его (до $12 \%$ ) существенно меньше, чем клинопироксена (до $28 \%$ ), который образуется при более низких температуpax, начиная с $1230{ }^{\circ} \mathrm{C}$ (рис. 11). Обращает на себя внимание сходство этих параметров со всеми полученными другими методиками температурными характеристиками для клинопироксена. В случае оливина температуры согласуются с данными моделирования по программе PETROLOG [27].

Расчеты условий кристаллизации пород по разрезу массива Медек были проведены для исходного расплава $(\mathrm{MgO}$ - 17,85 мас. \%) при условиях изобарической системы - 4 кбар. Буфер QFM. Coдержание воды - 0,5 мас. \%. Наличие данных по реальным составам оливинов в образцах, отобранных по разрезу скважины [28], позволяет оценить достоверность результатов расчетного моделирования.

В настоящий момент расположение массива Медек перевернуто по отношению к его первичному залеганию [28]. В связи с этим на рис. 12 с данными по расчетному моделированию процессов кристаллизации в исходной камере метраж по скважине идет в обратном направлении - снизу вверх. Соответственно максимальным температурам (около $1380-1350{ }^{\circ} \mathrm{C}$ ) кристаллизации оливина (на нижних уровнях камеры) соответствует его состав с максимальными значениями форстеритового компонента. Далее при понижении температуры до $1300-1270{ }^{\circ} \mathrm{C}$ (в средних горизонтах камеры, отметки скважины 250-350 м) расчетное со-
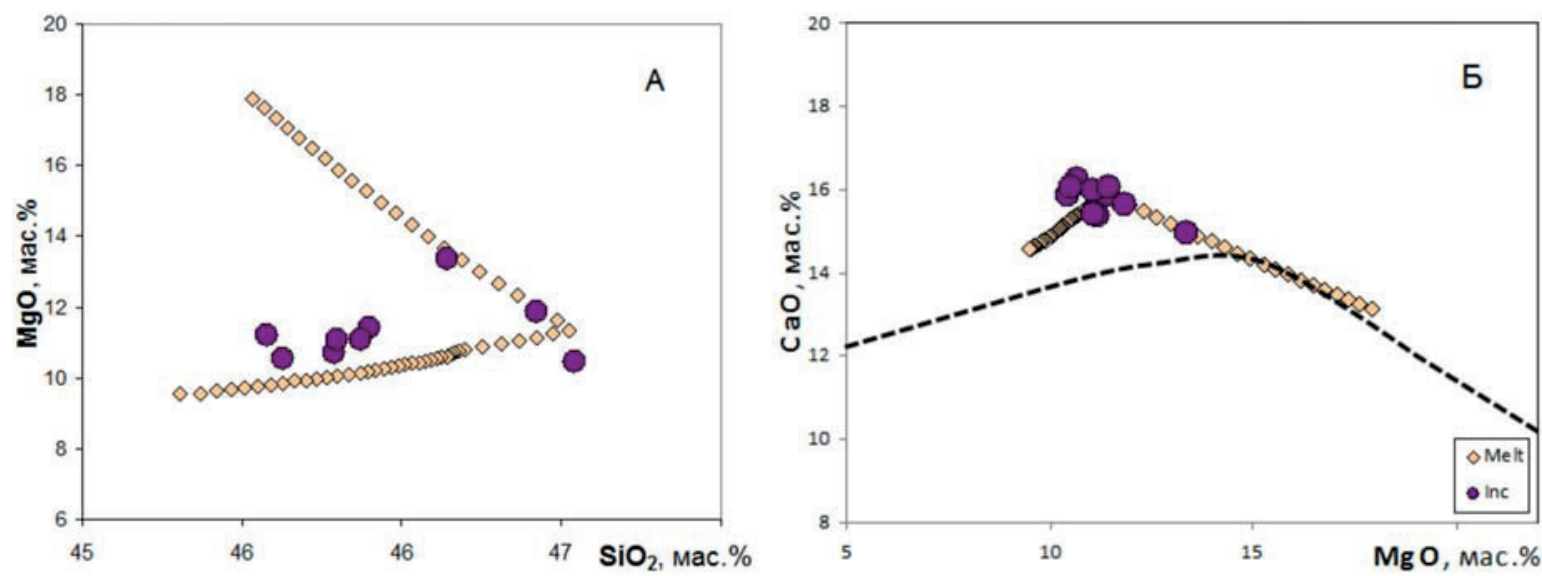

Рис. 10. Эволюиия состава исходного расплава (MgO - 17,85 мас. \%) в ходе его фракиионной кристаллизации. Меlt-состав расплава; Inc-состав стекла расплавных включений первого типа в хромшпинелидах из верлитов массива Медек. Пунктиром показан тренд составов расплавных включений в хромшпинелидах из дунитов Карашатского массива, Южная Тува [41]. Расчетное моделирование с помощью програмлы СОМАGMAT [25, 26]

Fig. 10. Evolution of the initial melt composition ( $\mathrm{MgO}-17,85 \mathrm{wt} . \%)$ during its fractional crystallization. Melt is the melt composition; Inc is the composition of glass of melt inclusions of the first type in Cr-spinel from wehrlite of Medek massif. The dashed line shows the trend of compositions of melt inclusions in Cr-spinel from dunites Karachat array, southern Tuva [41]. Computational modeling using COMAGMAT [25, 26] 
держание Fo практически совпадает с данными по реальным анализам оливинов.

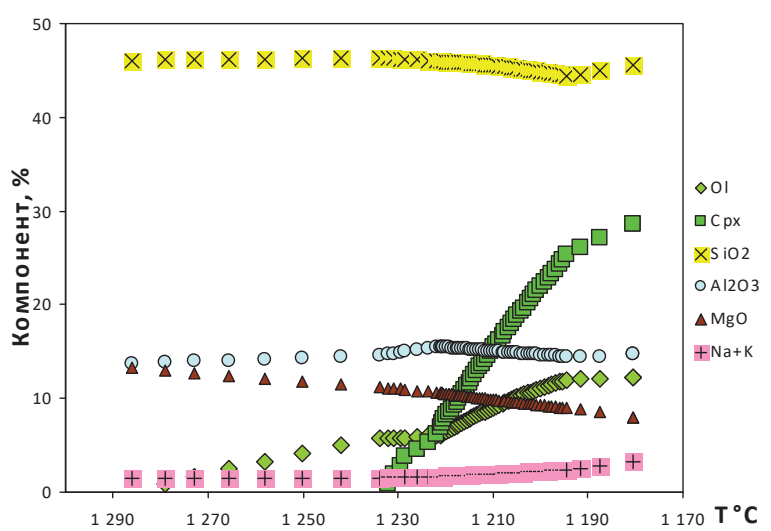

Рис. 11. Фракиионная кристаллизация пикробазальтового рас плава состава стекла прогретого расплавного включе ния первого типа (с максимальныл $\mathrm{MgO}$ - 13,36 мас. \%) в хромшпинелиде из верлитов массива Медек

Fig. 11. Fractional crystallization of the picrobasalt melt of the glass composition of the heated melt inclusion of the first type (with a maximum $\mathrm{MgO}-13,36 \mathrm{wt} . \%$ ) in Cr-spinel from wehrlite of the Medek massif

В последующем (с $1240-1230{ }^{\circ} \mathrm{C}$, около отметки 380-400 м) начинается интенсивная кристаллизация клинопироксена, преобладающая над образованием оливина, состав которого (как расчетный, так и реальный) существенно меняется с падением форстеритового компонента - формируются верлиты на самых верхних уровнях камеры (рис. 12). Таким образом, расчеты показывают возможность фракционной кристаллизации оливина (начиная с температур $1380{ }^{\circ} \mathrm{C}$ ) из исходного пикритоидного расплава ( $\mathrm{MgO}$ - 17,85 мас. \%), приводящей к заполнению оливиновыми кумулятами (формирование дунитов) основного объема (до 400 из 500 м по вертикали) реальной камеры и сменяющейся при температурах $1240-1230{ }^{\circ} \mathrm{C}$ интенсивной кристаллизацией клинопироксенов, приводящей к образованию в верхних горизонтах камеры пироксеноливиновых кумулятов - верлитов. Необходимо подчеркнуть, что данная модель подтверждается фактическим материалом - на рис. 12 отчетливо видна (особенно в верхней половине) хорошая согласованность расчетных и реальных данных по составам оливина.

В целом следует отметить, что при моделировании по программе COMAGMAT [25, 26] фракционной кристаллизации как пикробазальтового, так и исходного пикритоидного расплавов массива Медек, расчеты показывают образование плагиоклаза, начиная примерно с $1200{ }^{\circ} \mathrm{C}$. Возможность формирования плагиоклаз содержащих пород из подобных расплавов подтверждается данными по соседним (родственным) массивам: Медвежий Лог, Тартайском и Малая Шита, в которых присутствует оливиновое габбро [28]. В случае массива Медек, кристаллизовавшиеся первыми (при наиболее высоких температурах) оливины (и далее клинопироксены) осаждались в нижних горизонтах магма- тической камеры, формируя оливиновые и в меньшей степени оливин-пироксеновые кумуляты. Плагиоклаз, благодаря своей меньшей плотности, неизбежно оказывался на верхних уровнях. Так как массив Медек сейчас находится в перевернутом положении, изначально верхняя его часть (с плагиоклазом), в отличие от соседних массивов, имела мало шансов сохраниться.

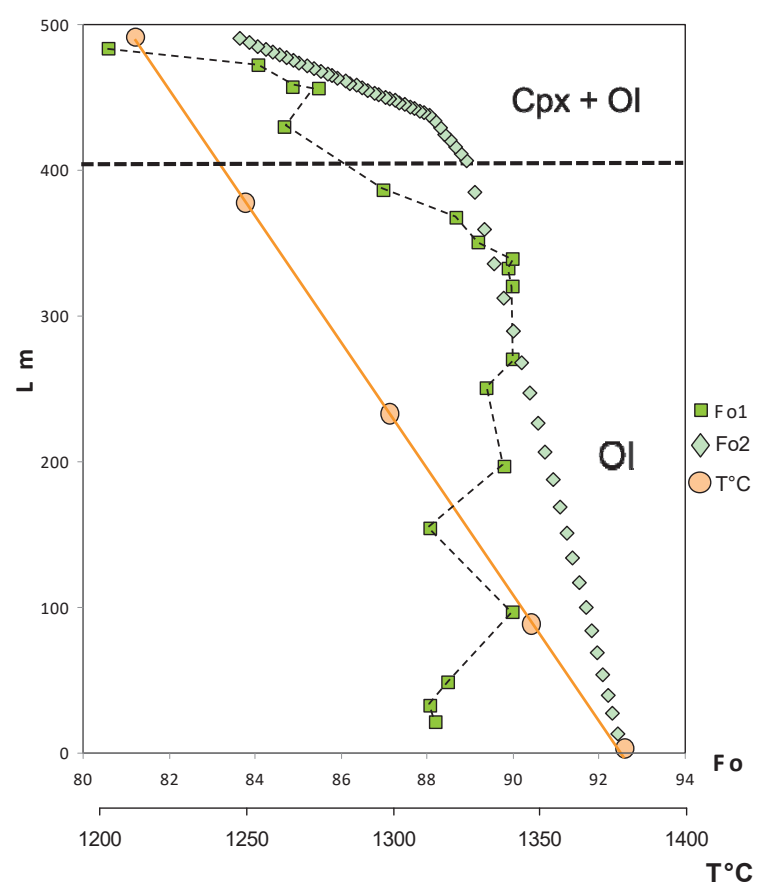

Рис. 12. Изменение состава оливина по разрезу массива Медек. Fo1 - значения реального форстеритового компонента, измеренного в образиах, отобранных по разрезу скважины; Fo2 - расчетные значения форстеритового компонента; $T^{\circ} \mathrm{C}$ - расчетные телпературы кристаллизации минералов из исходного расплава ( $\mathrm{MgO}$ - 17,85 мас. \%); Сpx+Ol и Ol- уровни кристаллизации минеральных парагенезисов соответственно верлита и дунита массива Медек; Lm - глубины пробоотбора керна скважины, м. Расчетное моделирование с помощью програмлы COMAGMAT [25, 26]. Рисунок составлен на основе оригинальных данных с использованием материалов из рабоmbl [28]

Fig. 12. Changes in olivine composition in the section of the Medek massif. Fo1 are the values of the real forsterite component measured in samples taken from the well section; Fo2 are the calculated values of the forsterite component; $T{ }^{\circ} \mathrm{C}$ are the calculated crystallization temperatures of minerals from the initial melt ( $\mathrm{MgO}-17,85 \mathrm{wt} . \%)$; $\mathrm{Cpx}+\mathrm{Ol}$ and $\mathrm{Ol}$ are the levels of crystallization of mineral assemblages, respectively wehrlite and dunite of the massif Medek; Lm are the well core sampling depths, $m$. Computational modeling using COMAGMAT program [25, 26]. The figure is based on the original data using materials from the work [28]

\section{Заключение}

1. В результате анализа стекол гомогенизированных расплавных включений установлено, что исходная магма для верлитов массива Медек отвечала по составу низкокалиевому пикробазальтовому расплаву, наиболее близкому по пе- 
трохимическим характеристикам к данным по расплавным включениям в хромитах из океанических комплексов.

2. Геобарометрические расчеты и моделирование фазовых равновесий по программе COMAGМАТ показали, что давление при формировании пород массива было около 4 кбар (2,8-4,7 кбар).

3. Совместное использование минералогических термометров и расчетов по программам PETROLOG и COMAGMAT, основанных на результатах экспериментальных исследований, свидетельствует о формировании дунитов массива из пикритоидного (MgO - 17,85 мас. \% ) расплава, начиная с кристаллизации оливина при $1380{ }^{\circ} \mathrm{C}$. При этом формирование верлитов происходило преимущественно из пикробазальтового $(\mathrm{MgO}-13,36$ мас. \%) расплава с кристаллизацией оливина начиная с $1280-1275^{\circ} \mathrm{C}$, но в гораздо меньших количествах, чем клинопироксена, интенсивное образование которого

\section{СПИСОК ЛИТЕРАТУРЫ}

1. Barnes S.J., Lightfoot P.C. Formation of magmatic nickel-sulfide ore deposits and processes affecting their copper and platinum-group element contents // Economic Geology 100th Anniversary Volume. - 2005. - P. 179-214.

2. Platinum group element. Chromium and vanadium deposits in mafic and ultramafic rocks / R.G. Cawthorn, S.J. Barnes, C. Ballhaus, K.N. Malich // Economic Geology 100th Anniversary Volume. - 2005. - P. 215-249.

3. The mineral system approach applied to magmatic Ni-Cu-PGE sulphide deposits / S.J. Barnes, A.R. Cruden, N.T. Arndt, B.M. Saumur // Ore Geology Reviews. - 2016. - V. 76. P. 296-316.

4. Barnes S.J., Robertson J.C. Time scales and length scales in magma flow pathways and the origin of magmatic $\mathrm{Ni}-\mathrm{Cu}-\mathrm{PGE}$ ore deposits // Geoscience Frontiers. - 2019. - V. 10. - № 1. P. 77-87.

5. Платинометальные месторождения мира. I. Платинометальные малосульфидные месторождения в ритмично расслоённых комплексах / Д.А. Додин, Н.М. Чернышев, Д.В. Полферов, Л.Л. Тарновецкий. - М.: А0 Геоинформарк, 1994. - 279 с.

6. Naldrett A.J. World-class $\mathrm{Ni}-\mathrm{Cu}-\mathrm{PGE}$ deposits: key factors in their genesis // Mineralium Deposita. - 1999. - V. 34. P. 227-240.

7. Додин Д.А., Чернышев Н.М., Яцкевич Б.А. Платинометальные месторождения России. - СПб.: Наука, 2000. - 755 с.

8. Naldrett A.J. From the mantle to the bank: the life of a $\mathrm{Ni}-\mathrm{Cu}-(\mathrm{PGE})$ sulfide deposit // South African Journal of Geology. -2010 . - V. 113.1. - P. 1-32.

9. Соболев А.В. Включения расплавов в минералах как источник принципиальной петрологической информации // Петрология. - 1996. - Т. 4. - № 3. - С. 228-239.

10. Primitive basaltic melts included in podiform chromites from the Oman ophiolite / P. Schiano, R. Clocchiatti, J.-P. Lorand, D. Massare, E. Deloule, M. Chaussidon // Earth and Planetary Science Letter. - 1997. - V. 146. - № 3-4. - P. 489-497.

11. Состав магматогенных флюидов. факторы их геохимической специализации и металлоносности / Л.С. Борисенко, Л.А. Боровиков, Л.М. Житова, Г.Г. Павлова // Геология и геофизика. - 2006. - Т. 47. - № 12. - С. 1308-1325.

12. Рябчиков И.Д., Когарко ЈІ.Н., Соловова И.П. Физико-химические условия магмообразовання в основании Сибирского плю- шло при более низких температурах (начиная с $\left.1235-1230{ }^{\circ} \mathrm{C}\right)$.

4. Сравнительный анализ результатов расчетного моделирования составов расплавов и минералов с данными по расплавным включениям и по реальным оливинам и клинопироксенам свидетельствует об их согласованности. В частности, важным является факт расположения составов расплавных включений вдоль расчетных трендов изменения расплава (рис. 10, А, Б), то есть здесь экспериментальные данные по включениям с одной стороны подтверждают достоверность проведенных расчетов, а с другой - такое соотношение показывает, что включения не являются случайностью, а фиксируют закономерную и теоретически обоснованную эволюцию расплава.

Работа выполнена в ралках государственного задания ИГМ СО РАН (проект № 0330-2016-0014) и ИГХ СО РАН (проект № 0350-2016-0030), при поддержке Министерства науки и высшего образования Российской Федеращии, договора № 14.Y26.31.0029.

ма по данным исследования расплавных микровключений в меймечитах и щелочных пикритах Маймеча-Котуйской провинции // Петрология. - 2009. - Т. 17. - № 3. - С. 311-322.

13. Условия кристаллизации дунитов Кондерского платиноносного щелочно-ультраосновного массива, Юго-Восток Алданского щита / В.А. Симонов, В.С. Приходько, С.В. Ковязин, А.В. Тарнавский / / Тихоокеанская геология. - 2010. - Т. 29. № 5. - C. 44-55.

14. Симонов В.А., Приходько В.С., Ковязин С.В. Условия формирования платиноносных ультраосновных массивов Юго-Востока Сибирской платформы // Петрология. - 2011. - Т. 19. № 6. - С. 579-598.

15. Васильев Ю.Р., Гора М.П. Меймечит-пикритовые ассоциации Сибири, Приморья и Камчатки (сравнительный анализ, вопросы петрогенезиса) // Геология и геофизика. - 2014. - Т. 55. № 8. - C. 1211-1225.

16. Петрогенезис дунитов Гулинского ультраосновного массива (север Сибирской платформы) / В.А. Симонов, Ю.Р. Васильев, С.И. Ступаков, А.В. Котляров, Н.С. Карманов // Геология и геофизика. - 2016. - Т. 57. - № 12. - С. 2153-2177.

17. Chromian spinels from the Magura Unit (Western Carpathians. Eastern Slovakia) - their petrogenetic and palaeogeographic implications / K. Bonova, J. Spisiak, J. Bona, M. Kovacik // Geological Quarterly. - 2017. - V. 61. - № 1. - P. 3-18.

18. Renna M.R., Tribuzio R., Ottolini L. New perspectives on the origin of olivine-rich troctolites and associated harrisites from the Ligurian ophiolites (Italy) // Journal of the Geological Society. 2016. - V. 173. - № 6. - Р. 916-932.

19. Среднее содержание летучих компонентов. петрогенных и редких элементов в магматических расплавах главных геодинамических обстановок земли. I. Расплавы основного состава / В.Б. Наумов, В.А. Дорофеева, А.В. Гирнис, В.В. Ярмолюк // Геохимия. - 2017. - № 7. - С. 618-643.

20. Миронов Н.Л., Портнягин М.В. Связь окислительно-восстановительных условий плавления мантии и содержаний меди и серы в первичных магмах на примере Толбачинского дола (Камчатка) и хребта Хуан де Фука (Тихий океан) // Петрология. -2018. - Т. 26. - № 2. - С. 140-162.

21. Физико-химические условия кристаллизации пород ультраосновных массивов Сибирской платформы / В.А. Симонов, В.С. Приходько, Ю.Р. Васильев, А.В. Котляров // Тихоокеанская геология. - 2017. - Т. 36. - № 6. - С. 70-93. 
22. Условия формирования ультрабазитов Алхадырского террейна (Восточный Саян. Сибирь) по результатам комплексного изучения состава хромшпинелидов / Ю.П. Бенедюк, В.А. Симонов, А.С. Мехоношин, Т.Б. Колотилина, С.И. Ступаков, А.А. Дорошков // Геология и геофизика. - 2015. - Т. 56. № 9. - C. 1664-1680.

23. Связь платиноносных ультрамафит-мафитовых интрузивов с крупными изверженными провинциями (на примере Сибирского кратона) / А.С. Мехоношин, Р. Эрнст, У. Седерлунд, М.А. Гамильтон, Т.Б. Колотилина, А.Э. Изох, Г.В. Поляков, Н.Д. Толстых // Геология и геофизика. - 2016. - Т. 57. № 5. - C. 1043-1057.

24. Арискин А.А., Бармина Г.С. Моделирование фазовых равновесий при кристаллизации базальтовых магм. - М.: Наука. «МАИК/Интерпериодика», 2000. - 363 с.

25. Ariskin A.A., Barmina G.S. COMAGMAT: Development of a magma crystallization model and its petrologic applications // Geochemistry International. - 2004. - V. 42 (Supp. 1). P. S1-S157.

26. The COMAGMAT-5: Modeling the Effect of Fe-Ni Sulfide Immiscibility in Crystallizing Magmas and Cumulates / A.A. Ariskin, K.A. Bychkov, G.S. Nikolaev, G.S. Barmina // Journal of Petrology. - 2018. - V. 59. - № 2. - P. 283-297.

27. Danyushevsky L.V., Plechov P.Yu. Petrolog 3: Integrated software for modeling crystallization processes // Geochemistry. Geophysics. Geosystems. - 2011. - V. 12. - № 7. C. Q07021. DOI: $10.1029 / 2011 \mathrm{GC} 003516$

28. Мехоношин А.С., Колотилина Т.Б., Дорошков А.А. Геохимическая модель формирования платиноносного дунит-верлитового массива Медек (Восточный Саян. Россия) // Геология и геофизика. - 2018. - Т. 59. - № 12. - С. 2011-2026.

29. Симонов В.А., Шарков Е.В., Ковязин С.В. Петрогенезис Fе-Ti интрузивных комплексов в районе Сьерра-Леоне. Центральная Атлантика // Петрология. - 2009. - Т. 17. - № 5. C. $521-538$.

30. Sobolev A.V., Danyushevsky L.V. Petrology and Geochemistry of Boninites from the North Termination of the Tonga Trench: Constraints on the Generation Conditions of Primary High-Ca Boninite Magmas // Journal of Petrology. - 1994. - V. 35. - P. 1183-1211.

31. Перчук Л.Л. Пироксеновый барометр и пироксеновые геотермометры // Доклады Академии наук. - 1980. - Т. 233. № 6. - C. 1196-2000.

32. Lindnsley D.H., Dixon S.A. Pyroxene thermometry // American Mineralogist. - 1983. - V. 68. - P. 477-493.
33. Ashchepkov I.V. Clinopyroxene Jd Barometer for mantle peridotites and eclogites and thermal conditions of the lithospheric keels of cratons and their surroundings. A Geo Odyssey // GSA Annual Meeting. - Boston, 2001. - P. ID 11658.

34. Monomineral universal clinopyroxene and garnet barometers for peridotitic, eclogitic and basaltic systems / I.V. Ashchepkov, T. Ntaflos, A.M. Logvinova, Z.V. Spetsius, H. Downes, N.V. Vladykin // Geoscience Frontier. - 2017. - V. 8. - № 4. - P. 775-795.

35. Schmidt M.W. Amphibole composition in tonalite as a function of pressure: an experimental calibration of the $\mathrm{Al}$-in-hornblende barometer // Contrib. Mineral. - Petrology. - 1992. - V. 110. - P. 304-310.

36. Hammarstrom J.M., Zen E.A. Aluminum in hornblende: an empirical igneous geobarometer // American Mineralogist. - 1986. V. 71. - P. 1297-1313.

37. Anderson J.L., Smith D.R. The effects of temperature and $\mathrm{fO}_{2}$ on the Al-in-hornblende barometer // American Mineralogist. 1995. - V. 80. - P. 549-559.

38. Krawczynski M.J., Grove T.L., Behrens H. Amphibole stability in primitive arc magmas: effects of temperature, $\mathrm{H} 20$ content, and oxygen fugacity // Contribution to Mineralogy and Petrology. 2012. - V. 164. - P. 317-339.

39. Симакин А.Г., Шапошникова 0.Ю. Новый амфиболовый геобарометр для высокомагнезиальных андезитовых и базальтовых магм // Петрология. - 2017. - Т. 25. - № 2. - С. 215-230.

40. Nomenclature of amphiboles: Report of the Subcommittee on Amphiboles of the International mineralogical Association, Commission on New Minerals and Mineral Names / B.E. Leake, A.R. Woolley, C.E.S. Arps, W.D. Birch, M.C. Gilbert, J.D. Grice, F.C. Hawthorne, F. Kato, H.J. Kisch, V.G. Krivovichev, K. Linthout, J. Laird, J.A. Mandarino, W.V. Maresch, E.H. Nickel, N.M.S. Rock, J.C. Schumacher, D.C. Smith, N.C.N. Stephenson, L. Ungaretti, E.J.W. Whittaker, Y.Z. Guo // American Mineralogist. - 1997. - V. 82. - P. 1019-1037.

41. Симонов В.А., Шелепаев Р.А., Котляров А.В. Физико-химические параметры формирования расслоенного габбро-гипербазитового комплекса в офиолитах Южной Тувы // Ультрабазитбазитовые комплексы складчатых областей и связанные с ними месторождения: Материалы третьей международной конференции. - Екатеринбург: Институт геологии и геохимии Уp0 PAH, 2009. - T. 2. - C. 195-198.

42. Магматические горные породы. - М.: Наука, 1983. - Т. 1. $766 \mathrm{c.}$

\section{Информация об авторах}

Ступаков С.И., кандидат геолого-минералогических наук, старший научный сотрудник Института геологии и минералогии им. В.С. Соболева Сибирского Отделения Российской Академии Наук.

Симонов B.A., доктор геолого-минералогических наук, главный научный сотрудник Института геологии и минералогии им. В.С. Соболева Сибирского Отделения Российской Академии Наук; профессор Новосибирского национального исследовательского государственного университета; профессор Казанского федерального университета.

Мехоношин A.C., кандидат геолого-минералогических наук, старший научный сотрудник Института геохимии им. А.П. Виноградова Сибирского Отделения Российской Академии Наук; профессор Иркутского национального исследовательского технического университета.

Колотилина T.Б., кандидат геолого-минералогических наук, старший научный сотрудник Института геохимии им. А.П. Виноградова Сибирского Отделения Российской Академии Наук; доцент Иркутского национального исследовательского технического университета. 
UDC 550.4: 548.4

\title{
EVOLUTION OF PHYSICO-CHEMICAL CONDITIONS OF CRYSTALLIZATION OF MELTS DURING FORMATION OF DUNITE-PERIDOTITE-GABBROIC MASSIFS OF THE EASTERN SAYAN
}

\author{
Sergey I. Stupakov ${ }^{1}$,
}

stupakov@igm.nsc.ru

Vladimir A. Simonov ${ }^{12,3}$,

simonov@igm.nsc.ru

Sergey A. Mekhonoshin ${ }^{4,5}$

mekhonos@igc.irk.ru

\section{Tatyana B. Kolotilina ${ }^{4,5}$,}

tak@igc.irk.ru

1 V.S. Sobolev Institute of Geology and Mineralogy SB RAS,

3, Academician Koptyug Avenue, Novosibirsk, 630090, Russia.

${ }^{2}$ Novosibirsk National Research State University,

1, Pirogov street, Novosibirsk, 630090, Russia.

${ }^{3}$ Kazan Federal University,

18, Kremlevskaya street, Kazan, 420008, Russia.

${ }^{4}$ A.P. Vinogradov Institute of Geochemistry SB RAS,

1A, Favorsky street, Irkutsk, 664033, Russia.

${ }^{5}$ Irkutsk National Research Technical University,

83, Lermontov street, Irkutsk, 664074, Russia.

The relevance of the research. The study of melt inclusions in minerals is one of the most reliable ways of obtaining direct information on the nature of magmatic processes, allows building a model of formation of intrusions and tracing the evolution of physico-chemical conditions of crystallization of magmatic complexes.

The main aim of the research is to prove the magmatic origin of rocks of this massif, which makes it possible to consider the distribution of noble metals in melts, based on the available experimental data.

Objects: melt inclusions in Cr-spinel from dunites and wehrlites Medek basite-ultrabasite massifs.

Methods. The search for melt inclusions was carried out in accessory Cr-spinel sample isolated from dunites and wehrlite, to determine the nature of the high temperature experiments. For this purpose, the samples were taken (about 50-100 grains of $\mathrm{Cr}$-spinel fraction $0,2-0,5 \mathrm{~mm}$ ) and placed in a graphite microcontainer with internal dimensions in the first millimeters. Micro containers were tightly closed with graphite covers. Thus, the Cr-spinel in these containers were at temperatures above $1000{ }^{\circ} \mathrm{C}$ under reducing conditions as a result of the reaction of air oxygen with graphite. The experiments were carried out at high temperatures on the basis of existing methods of investigation of melt inclusions. For maximum transformation of the melt in inclusions into homogeneous glass, quenching into water was carried out. The choice of the temperature regime $\left(1280-1300^{\circ} \mathrm{C}\right)$ was determined primarily by the fact that the main task of hightemperature experiments was to melt the contents of inclusions and to obtain glass during hardening, which was then analyzed on a microprobe and a scanning microscope.

Result. Conducted research of homogenised melt inclusions glass showed that crystallization of $\mathrm{Cr}$-spinel and containing wehrlite of the ultrabasic Medek massif (East Sayan) were involved in low potassium picrobasalt of melts of normal alkalinity, of the most similar petrochemical characteristics to the data on melt inclusions in $\mathrm{Cr}$-spinel from oceanic complexes. The calculations were made for various mineralogical barometers and different models of crystallization on the basis of compositions of glasses of heated melt inclusions in $\mathrm{Cr}$ spinel in the COMAGMAT program, which showed that the pressure in formation of massive rocks was about $4 \mathrm{kbar}(2,8-4,7 \mathrm{kbar})$; the combined use of mineralogical thermometers and calculations on the basis of glass compositions of heated melt inclusions in $\mathrm{Cr}$-spinel according to PETROLOG and COMAGMAT programs allows us to speak about the formation of dunites from picritoids (MgO 17,85 wt. \%) of the melt, since the crystallization of olivine at $1380^{\circ} \mathrm{C}$, the formation of wehrlite occurred mainly from picrobasalt (MgO 13,36 wt. \%) of the melt with the crystallization of olivine starting from $1280-1275^{\circ} \mathrm{C}$, but in much smaller quantities than clinopyroxene, the intensive formation of which was at lower temperatures (starting from $1235-1230^{\circ} \mathrm{C}$ ); a comparative analysis of the results of computational modeling of melt and mineral compositions with data on melt inclusions and real olivines and clinopyroxenes indicates their consistency, as evidenced by the fact of the location of melt inclusions along the calculated trends of melt change, that is, experimental data on inclusions on the one hand confirm the reliability of the calculations, and on the other - this ratio shows that the inclusions are not an accident, but record the natural and theoretically justified evolution of the melt.

\section{Key words:}

Medek intrusion, ultrabasic rocks, dunites, wehrlite, Cr-spinel, melt inclusions.

The research was carried out within the State Task IGM SB RAS (project no. 0330-2016-0014) and IGC SB RAS (project no. 0350-2016-0030), supported by the Ministry of Science and Higher Education of the Russian Federation, agreement no. 14.Y26.31.0029. 


\section{REFERENCES}

1. Barnes S.J., Lightfoot P.C. Formation of magmatic nickel-sulfide ore deposits and processes affecting their copper and platinumgroup element contents. Economic Geology 100th Anniversary Volume, 2005, pp. 179-214.

2. Cawthorn R.G., Barnes S.J., Ballhaus C., Malich K.N. Platinum group element. chromium and vanadium deposits in mafic and ultramafic rocks. Economic Geology 100th Anniversary Volume, 2005, pp. 215-249.

3. Barnes S.J., Cruden A.R., Arndt N.T., Saumur B.M. The mineral system approach applied to magmatic $\mathrm{Ni}-\mathrm{Cu}-\mathrm{PGE}$ sulphide deposits. Ore Geology Reviews, 2016, vol. 76, pp. 296-316.

4. Barnes S.J., Robertson J.C. Time scales and length scales in magma flow pathways and the origin of magmatic $\mathrm{Ni}-\mathrm{Cu}-\mathrm{PGE}$ ore deposits. Geoscience Frontier, 2019, vol. 10, no. 1, pp. 77-87.

5. Dodin D.A., Chernyshov N.M., Polferov D.V., Tarnovetskii L.L. Platinometallnye mestorozhdeniya Mira. T. 1. Kniga 1. Malosulfidnye mestorozhdeniya $v$ ritmichno rassloennykh kompleksakh [PGM Deposits of the World. Vol. 1. B. 1. Low sulfide PGM deposits in rhythmically Layered Complexes]. Moscow, Geoinfrmmark Publ., 1994. 279 p.

6. Naldrett A.J. World-class Ni-Cu-PGE deposits: key factors in their genesis. Mineralium Deposita, 1999, vol. 34, pp. 227-240.

7. Dodin D.A., Chernyshov N.M., Yatskevich B.A. Platinometalnye mestorozhdeniya Rossii [PGM Deposits of Russia]. St. Petersburg, Nauka Publ., 2000. 755 p.

8. Naldrett A.J. From the mantle to the bank: the life of a Ni-Cu(PGE) sulfide deposit. South African Journal of Geology, 2010, vol. 113.1, pp. 1-32.

9. Sobolev A.V. Melt inclusions in minerals as a source of principle petrological information. Petrology, 1996, vol. 4, no 3, pp. 209-220.

10. Schiano P., Clocchiatti R., Lorand J.-P., Massare D., Deloule E., Chaussidon M. Primitive basaltic melts included in podiform chromites from the Oman ophiolite. Earth Planetary Science Letter, 1997, vol. 146, no. 3-4, pp. 489-497.

11. Borisenko L.S., Borovikov L.A., Zhitova L.M., Pavlova G.G. Composition of magmatogene fluids and factors of their geochemical specialization and metal-bearing capacity. Russian Geology and Geophysics, 2006, vol. 47, no. 12, pp. 1282-1300.

12. Ryabchikov I.D., Kogsrko L.N., Solovova I.P. Physicochemical conditions of magma formation at the base of the Siberian plume: Insight from the investigation of melt inclusions in the meymechites and alkali picrites of the Maimecha-Kotui province. Petrology, 2009, vol. 17, no. 3, pp. 287-299.

13. Simonov V.A., Prikhodko V.S., Kovyazin S.V., Tarnavskiy V.A. Crystallization conditions of dunites in the Konder platiniferous alkaline-ultramafic massif of the southeastern Aldan Shield. Russian Journal of Pacific Geology, 2010, vol. 4, no. 5, pp. 429-440.

14. Simonov V.A., Prikhodko V.S., Kovyazin S.V. Genesis of Platiniferous massifs in the Southeastern Siberian Platform. Petrology, 2011, vol. 19, no. 6, pp. 549-567.

15. Vasilev Y.R., Gora M.P. Meimechite-picrite associations in Siberia, Primorye, and Kamchatka (comparative analysis and petrogenesis). Russian Geology and Geophysics, 2014, vol. 55, no. 8, pp. 959-970.

16. Simonov V.A., Vasiliev Y.R., Stupakov S.I., Kotlyarov A.V., Karmanov N.S. Petrogenesis of dunites of the Guli ultrabasic massif (northern Siberian Platform). Russian Geology and Geophysics, 2016, vol. 57, no. 12, pp. 1696-1715.

17. Bonova K., Spisiak J., Bona J., Kovacik M. Chromian spinels from the Magura Unit (Western Carpathians. Eastern Slovakia) their petrogenetic and palaeogeographic implications. Geological Quarterly, 2017, vol. 61, no. 1, pp. 3-18.

18. Renna M.R., Tribuzio R., Ottolini L. New perspectives on the origin of olivine-rich troctolites and associated harrisites from the
Ligurian ophiolites (Italy). Journal of the Geological Society, 2016, vol. 173, no. 6, pp. 916-932.

19. Naumov V.B., Dorofeeva V.A., Girnis A.V., Yarmoluk V.V. Mean concentrations of volatile components, major and trace elements in magmatic melts in major geodynamic environments on Earth. I. Mafic melts. Geochemistry International, 2017, vol. 55, no. 7, pp. 629-653.

20. Mironov N.L., Portnyagin M.V. Coupling of redox conditions of mantle melting and copper and sulfur contents in primary magmas of the Tolbachinsky Dol (Kamchatka) and Juan de Fuca Ridge (Pacific Ocean). Petrology, 2018, vol. 26, no. 2, pp. 145-166.

21. Simonov V.A., Prikhodko V.S., Vasilev V.S., Kotlyarov A.V. Physicochemical Conditions of Crystallization of Rocks from Ultrabasic Massifs of the Siberian Platform. Russian Journal of $P a$ cific Geology, 2017, vol. 11, no. 6, pp. 447-468.

22. Benedyuk Yu.P., Simonov V.A., Mekhonoshin A.S., Kolotilina T.B., Stupakov S.I., Doroshkov A.A. Genesis of ultramafic rocks of the Alkhadyr terrane (East Sayan, Siberia): implications from the data on Cr-spinel compositions. Russian Geology and Geophysics, 2015, vol. 56, no. 9, pp. 1308-1321.

23. Mekhonoshin A.S., Ernst R., Söderlund U., Hamilton M.A., Kolotilina T.B., Izokh A.E., Polyakov G.V., Tolstykh N.D. Relationship between platinum-bearing ultramafic-mafic intrusions and large igneous provinces (examplified by the Siberian Craton). Russian Geology and Geophysics, 2016, vol. 57 (5), pp. 822-833.

24. Ariskin A.A., Barmina G.S. Modelirovanie fazovykh ravnovesiy pri kristallizatsii bazaltovykh magm [Modeling phase equilibrium of basalt magmas]. Moscow, Nauka, MAIK/Interperiodika Publ., $2000.363 \mathrm{p}$.

25. Ariskin A.A., Barmina G.S. COMAGMAT: Development of a magma crystallization model and its petrologic applications. Geochemistry International, 2004, vol. 42 (Supp. 1), pp. S1-S157.

26. Ariskin A.A., Bychkov K.A., Nikolaev G.S., Barmina G.S. The COMAGMAT-5: Modeling the Effect of Fe-Ni Sulfide Immiscibility in Crystallizing Magmas and Cumulates. Journal of Petrology, 2018, vol. 59, no. 2, pp. 283-297.

27. Danyushevsky L.V., Plechov P.Yu. Petrolog 3: Integrated software for modeling crystallization processes. Geochemistry, Geophysics, Geosystems, 29 July, 2011, vol. 12, no. 7, pp. Q07021. DOI: $10.1029 / 2011 \mathrm{GC} 003516$.

28. Mekhonoshin A.S., Kolotilina T.B., Doroshkov A.A. Geochemical model for the formation of the Medek platinum-bearing dunitewehrlite massif (East Sayan, Russia). Russian Geology and Geophysics, 2018, vol. 59, no. 12, pp. 822-833.

29. Simonov V.A., Sharkov E.V., Kovyazin S.V. Petrogenesis of the Fe-Ti Intrusive Complexes in the Sierra Leone Region, Central Atlantic. Petrology, 2009, vol. 17, no. 5, pp. 488-502.

30. Sobolev A.V., Danyushevsky L.V. Petrology and Geochemistry of Boninites from the North Termination of the Tonga Trench: Constraints on the Generation Conditions of Primary High-Ca Boninite Magmas. J. Petrol., 1994, vol. 35, pp. 1183-1211.

31. Perchuk L.L. Pyroxene barometer and pyroxene geotermometers. Doklady Ras, 1980, vol. 233, no. 6, pp.1196-2000. In Rus.

32. Lindnsley D.H., Dixon S.A. Pyroxene thermometry. Amer. Mineralogy, 1983, vol. 68. pp. 477-493.

33. Ashchepkov I.V. Clinopyroxene Jd Barometer for Mantle Peridotites and Eclogites and Thermal Conditions of the Lithospheric Keels of Cratons and their Surroundings. A Geo Odyssey. GSA Annual Meeting, November 1-10, Boston, 2001. P. ID 11658.

34. Ashchepkov I.V., Ntaflos T., Logvinova A.M., Spetsius Z.V., Downes H., Vladykin N.V. Monomineral universal clinopyroxene and garnet barometers for peridotitic, eclogitic and basaltic systems. Geoscience Frontier, 2017, vol. 8, no. 4, pp. 775-795.

35. Schmidt M.W. Amphibole composition in tonalite as a function of pressure: an experimental calibration of the Al-in-hornblende barometer. Contrib. Mineral. Petrology, 1992, vol. 110, pp. 304-310. 
36. Hammarstrom J.M., Zen E.A. Aluminum in hornblende: an empirical igneous geobarometer. American Mineralogist, 1986, vol. 71, pp. 1297-1313.

37. Anderson J.L., Smith D.R. The effects of temperature and $\mathrm{fO}_{2}$ on the Al-in-hornblende barometer. American Mineralogist, 1995, vol. 80, pp. 1297-1313.

38. Krawczynski M.J., Grove T.L., Behrens H. Amphibole stability in primitive arc magmas: effects of temperature, $\mathrm{H} 20$ content, and oxygen fugacity. Contribution to Mineralogy and Petrology, 2012, vol. 164, pp. 317-339.

39. Simakin A.G., Shaposhnikova 0.Yu. New amphibole geobarometer for high-magnesium andesite and basalt magmas. Petrology, 2017, vol. 25, no. 2, pp. 215-230.

40. Leake B.E., Woolley A.R., Arps C.E.S., Birch W.D., Gilbert M.C., Grice J.D., Hawthorne F.C., Kato F., Kisch H.J., Krivovichev V.G., Linthout K., Laird J., Mandarino J.A., Maresch W.V., Nickel E.H., Rock N.M.S., Schumacher J.C.,
Smith D.C., Stephenson N.C.N., Ungaretti L., Whittaker E.J.W., Guo Y.Z., Nomenclature of amphiboles: Report of the Subcommittee on Amphiboles of the International mineralogical Association, Commission on New Minerals and Mineral Names. American Mineralogist, 1997, vol. 82. pp. 1019-1037.

41. Simonov V.A., Shelepaev R.A., Kotlyarov V.A. Fiziko-khimicheskie paramety formirovaniya rassloennogo gabbro-giperbasitovogo kompleksa v ofiolitakh Yuzhnoy Tuvy [Physico-chemical parameters of formation of layered gabbro-ultrabasic complex in the ophiolites of the southern Tuva]. Ultrabazit-bazitovye kompleksy skladchatykh oblastey b suyazannye s nimi mestorozhdeniya [U1trabasic-basic complexes of folded regions and related deposits]. Ekaterinburg, IGG UB RAS Publ., 2009. Vol. 2, pp. 195-198.

42. Izverzhennye gornye porody [Igneous rocks]. Moscow, Nauka Publ., 1983. Vol. 1, 766 p.

\section{Information about the authors}

Sergey I. Stupakov, Cand. Sc., senior researcher, V.S. Sobolev Institute of Geology and Mineralogy SB RAS.

Vladimir A. Simonov, Dr. Sc., chief researcher, V.S. Sobolev Institute of Geology and Mineralogy SB RAS; professor, Novosibirsk National Research State University; professor, Kazan Federal University.

Aleksey S. Mekhonoshin, Cand. Sc., senior researcher, A.P. Vinogradov Institute of Geochemistry SB RAS; professor, Irkutsk National Research Technical University.

Tatyana B. Kolotilina, Cand. Sc., senior researcher, A.P. Vinogradov Institute of Geochemistry SB RAS; associate professor, Irkutsk National Research Technical University. 